\title{
Identification of transcriptional regulatory elements in the human somatostatin receptor sst2 promoter and regions including estrogen response element half-site for estrogen activation
}

\author{
Nobuko Kimura, Nobuko Takamatsu, Yoshio Yaoita ${ }^{1}$, R Yoshiyuki Osamura ${ }^{2}$ \\ and Narimichi Kimura ${ }^{3}$ \\ Tokyo Metropolitan Institute for Neuroscience, Tokyo Metropolitan Organization for Medical Research, 2-6 Musashidai, Fuchu, Tokyo 183-8526, Japan \\ ${ }^{1}$ Division of Embryology and Genetics, Graduate School of Science, Institute for Amphibian Biology, Hiroshima University, Higashi-Hiroshima 739-8526, Japan \\ ${ }^{2}$ Department of Pathology, Tokai University School of Medicine, Isehara City, Kanagawa 259-1193, Japan \\ ${ }^{3}$ Tokyo Metropolitan Institute of Gerontology, Itabashi-ku, Tokyo 173-0015, Japan \\ (Correspondence should be addressed to N Kimura; Email: kimura @tmin.ac.jp)
}

\begin{abstract}
The somatostatin receptor subtype 2 (sst2) mediates inhibition of hormone secretion and cell proliferation, and modulates neurotransmission. Its expression is widespread in various normal tissues and many malignant cells, and is up-regulated by estrogen in breast cancer cells. This study was undertaken to investigate molecular mechanism of transcriptional regulation of the human sst2 gene, for which an additional exon (exon 1) in the $5^{\prime}$-untranslated region was recently found. Transient transfection and mutational analysis showed that the immediate $5^{\prime}$-upstream region containing two Sp1 $(-54 /-45$ and $-88 /-79)$ and an ATF/CRE $(-69 /-62)$ sites provided full promoter activity. An EMSA together with transfection analysis in Sp1-deficient Drosophila Schneider line (SL2) cells showed that Sp1 acted on the proximal Sp1 site, whereas Sp3, Sp1, and Sp2 did on the distal Sp1 site. Activating transcription factor-2 (ATF)-2, c-Jun, and cyclic AMP response element-binding protein (CREB) interacted with the ATF/CRE site. Transcriptional activation by estrogen occurred through two different regions; one included these proximal elements and the other existed in the upstream region containing estrogen response element (ERE) half-site $(-348 /-344)$ and GC-rich sequence $(-447 /-414)$. This upstream estrogen responsiveness was observed in a human breast cancer T47D cell, but not in $\mathrm{GH}_{3}$ or estrogen receptor $\alpha(E R \alpha)$-expressing HeLa cells, and was potentiated by overexpression of ER $\alpha$ or $E R \beta$, whose binding to the ERE half-site was verified by EMSAs. A chromatin immunoprecipitation assay suggested that $E R \alpha$ was recruited to the ERE half-site after estrogen treatment in T47D cells. The present results should provide a molecular basis for transcriptional regulation in a variety of physiological and pathological contexts of sst2-expressing tissues.
\end{abstract}

Journal of Molecular Endocrinology (2008) 40, 75-91

\section{Introduction}

Somatostatin, a neuropeptide originally isolated as a growth hormone $(\mathrm{GH})$ release-inhibiting hormone, is widely expressed in the central nervous system and peripheral organs including the gut, pancreas, thyroid, and immune cells (Patel 1999). The peptide exerts its effects by interacting with specific $\mathrm{G}$ protein-coupled somatostatin receptors. There exist five distinct somatostatin receptor subtypes (sst1-sst5), among which sst2 is well known to be involved in many physiological functions (Patel 1999, Reubi 2003, Krantic et al. 2004, Olias et al. 2004). These include inhibitory regulation of endocrine and exocrine secretions (Patel 1999), such as $\mathrm{GH}$, adrenocorticotrophin, glucagon, and gastric acid (Martinez et al. 1998, Ren et al. 2003, Ben-Shlomo et al.
2005). In central nervous system of an sst2-deficient mouse, GH-induced feedback suppression of GH secretion in GH-releasing hormone-secreting arcuate neurons is impaired (Zheng et al. 1997), and fine motor control, spatial learning, and neuronal plasticity are disordered (Dutar et al. 2002, Krantic et al. 2004, Olias et al. 2004). In a number of malignant cells, suppression of cell proliferation by somatostatin and its analogs is mediated via sst2 (Hofland \& Lamberts 2003, Reubi 2003). The immune system is also modulated through sst2 by somatostatin and cortistatin, a cyclic neuropeptide related to somatostatin (Dalm et al. 2003, Krantic et al. 2004). These functional properties of sst2 is well substantiated by not only its widespread expression in human normal tissues, such as pituitary, brain, pancreatic islets, adrenal gland, kidney, and 
blood lymphocytes (Yamada et al. 1992, Patel 1999), but also frequent and high expression in various tumors including GH-secreting pituitary adenoma, gastroenteropancreatic tumors, neuroblastomas, small cell lung carcinomas, and breast cancers (Hofland \& Lamberts 2003, Reubi 2003).

Despite its physiological and pathological importance, molecular mechanism underlying transcriptional regulation of the human sst 2 gene remains unclear. Previous reports showed that an initiator element, SSTR2inr, exists in proximal upstream of the coding region and forms a core promoter (Pscherer et al. 1996). The SSTR2inr contained $\mathrm{E}$ and TC boxes, with which SL3-3 enhancer factor 2 (SEF-2) and brainspecific c-myc intron-binding protein 1 (MIBP1) interacted as trans-factors respectively, although very limited expression of MIBP1 was reported in tissues and cell types such as brain and neuroblastoma (Dorflinger et al. 1999) and no definite transcriptional cis-elements were identified in the $5^{\prime}$-distal region of the SSTR2inr, except broad regions related to estrogen ( $\mathrm{Xu}$ et al. 1998), glucocorticoid (Petersenn et al. 1999), and transforming growth factor $\beta$-responsiveness (Puente et al. 2001). Recently, however, a finding by full-length human cDNA sequencing (Mammalian Gene Collection (MGC) Program Team; Strausberg et al. 2002) demonstrated an additional sequence (exon 1) in the $5^{\prime}$-UTR of the sst 2 gene, whose structural arrangement appeared to be extremely similar to those of corresponding genes of rat and mouse origins (Kraus et al. 1998, Kimura et al. 2001). These recent findings make it necessary to undertake more detailed analysis on the transcriptional regulation based on the newly reported human sst2 gene structural organization.

In a previous study, we found that the somatostatin responsiveness to inhibit prolactin release was provided by the administration of estrogen into a rat pituitary primary-cultured cell (Kimura et al. 1986). This phenomenon was attributed to an increased number of somatostatin receptor binding sites, a large part of which constituted sst2 (Kimura et al. 1989, 1998, Djordjijevic et al. 1998). Similar effects of estrogen on sst2 mRNA expression and sst2 binding activity were reported for human breast cancer cell lines $(\mathrm{Xu}$ et al. 1996). Importance of the estrogen-induced sst2 expression is recognized in the recent oncological studies, in which, for example, the effectiveness of endocrine therapy can be assessed with a whole-body imaging of ${ }^{99 \mathrm{~m}}$ Tc-labeled depreotide that binds to sst 2 since its expression associates with functional estrogen receptor (ER) positivity and may lead to a better clinical prognosis (Van Den Bossche et al. 2004, 2006, Orlando et al. 2004, Murdie 2006). Nevertheless, the mechanism of transcriptional regulation by estrogen has been poorly understood in the human sst 2 gene. The region required for the estrogen responsiveness is shown only in a broad region $(5 \cdot 3-3 \cdot 8 \mathrm{kbp})$ upstream of the translation initiation site of sst2 gene (Xu et al. 1998). These observations imply that the estrogen action may occur through $5^{\prime}$-upstream of the newly identified exon 1 of the human sst 2 gene.

The purpose of the present study is to elucidate molecular mechanisms underlying transcriptional regulation of the human sst 2 gene. We first characterized the $5^{\prime}$-flanking region of the human sst2 gene to identify cis- and trans-acting elements in a novel promoter and then investigated the mechanism by which estrogen up-regulates transcription of the human sst2 gene.

\section{Materials and methods}

\section{Materials}

The oligonucleotides and double-stranded oligonucleotides were obtained from BEX (Tokyo, Japan): S2-1, GGT TGA CAC CAC AGA GCG ATT GAG GTC; S2-2, CTC ATC CGC CAT GTC CAT GGC TGC; S2-3, CAG CTT GGC TAG CGC CTG GCG CCG GAC GT; S24, GTT CCT GGC TCC TCG ACC CTC TTG TGC C; S25, gac acg cgt CTG CCT AGA ATA TAT GGG TGG AAG GGA ATC GAC; S2-6, gac ctc gag GGC TGC TTT TCA GTC TTA GGC TAG TTC CAG; S2-7, CTC GCA AGA CCA CCA GCG CCC AGA; S2-8, GAA GCC GCT GTG ACG TAG CGG GAG GG; S2-9, GCC CCC CTC CCG CTA CGT CAC AGC GG; S2-10; AGG GGT TGG GGG GGC GGA GCG AA; S2-11, CGG CTT CGC TCC GCC CCC CCA AC; S2-12, CCT ACT CTT AGC CTG GCC CTG CG; S2-13, TCA CAG AGT CGA TTC CCT TCC AC; S2-14, GTG CTG GCG CCA CAA TCT CCG CTC TTG CCT; and S2-15, AGT GTC AGG ACC GCG GAG CCG GTT GCT. Consensus Sp1 and estrogen response element (ERE) oligonucleotides were purchased from Promega Corp. and Santa Cruz Biotechnology Inc. (Santa Cruz, CA, USA) respectively. ICI182780 and tamoxifen were obtained from Tocris Cookson Ltd (Ellisville, MO, USA) and Sigma-Aldrich respectively. Recombinant proteins of $\mathrm{ER} \alpha$ and $\mathrm{ER} \beta$ were obtained from Invitrogen Co.

\section{Determination of the transcription start site}

The transcription start site of the human sst2 gene was analyzed by SMART (Switching Mechanism At $5^{\prime}$-end of RNA Transcript) technology using SMART RACE cDNA amplification kit (Clontech Laboratories Inc.) as described previously (Kimura et al. 2001). In brief, total RNAs of the human brain and pancreas (Clontech Lab.) were reverse transcribed with M-MLV Reverse Transcriptase (RNase ${ }^{-}$Point Mutant, Promega) in the presence of SMARTII oligonucleotide at $42{ }^{\circ} \mathrm{C}$. The first-strand cDNA with the $5^{\prime}$-end of the additional 
SMART sequence was then amplified in the PCR mixture in the presence of LA-Taq DNA polymerase with GC buffer I (Takara, Osaka, Japan), deoxynucleotide triphosphates, sense universal primer mix, and an antisense primer of human sst2 (S2-1), and then nested PCRs were performed with the combination of a sensenested universal primer and an antisense-nested primer (S2-2). The PCR products were cloned into a pTA vector and analyzed by sequencing.

\section{Cloning of the $5^{\prime}$-flanking region of the human sst2 gene}

The $5^{\prime}$-flanking region of the transcription initiation site of the human $s s t 2$ gene was cloned by a previously reported method, using human Genome Walker Kits (Clontech Lab.; Kimura et al. 2001). The first PCR was performed with genomic libraries as the template and human sst2 cDNA primers (S2-3) as the antisense primers, and nested PCR was performed using a nested antisense primer (S2-4). For cloning of the full-length intron, PCR was performed with LA-Taq DNA polymerase, the human genomic EcoRV library, a sense primer S2-5, and an antisense primer S2-6.

\section{RT-PCR}

Total RNA samples were isolated with TRIzol reagent (Invitrogen Com.) according to the manufacturer's instructions. RNA samples were treated with DNase I to remove contaminating DNA before the RNAs were reverse transcribed using a random primer. PCR amplification of cDNA was performed essentially as described previously (Kimura et al. 1998, 2001). Primers of S2-7 and S2-2 were used for human sst2 (exons 1 and 2). Primers for human sst2 (exon 2) and human glyceraldehydes-3-phosphate dehydrogenase (GAPDH) were as previously described (Kimura et al. 2001). The cDNAs produced from $40 \mathrm{ng}$ total RNA were amplified using the primers of sst2 and GAPDH for 37 and 27 cycles respectively. No signal of PCR products was observed when amplification was performed in parallel in the absence of RT.

\section{Reporter and expression plasmids}

The full-length $5^{\prime}$-flanking region fragments of both exon $1(-3734 /+149)$ and exon $2(-325 /+4297)$ were cloned into a firefly luciferase reporter plasmid, pGL3-Basic (Promega Corp.), and deletion mutant plasmids were prepared. A distal enhancer region of rat prolactin (PRL) gene (Day \& Maurer 1989), which was from -1769 to -1495 of the translation initiation site, was cloned into a pGL3-Promoter Vector with SV40 promoter. Site-directed mutagenesis of the human sst2 promoter was performed using a Quick Change SiteDirected Mutagenesis Kit (Stratagene, La Jolla, CA, USA). Expression vectors, $\mathrm{pPac} 0$ and $\mathrm{pPacSp} 1$, were gifts from $\mathrm{R}$ Tjian (Courey \& Tjian 1988), and pPacSp2 and pPacSp3 vectors were gifts from $J$ D Noti (Noti 1997). The expression vectors of ERs (pSV2RcER and pCXN2hER $\beta$ ) and the pit-1 (pRSV-Pit-1) were generously supplied from M Muramatsu and S Inoue (Ogawa et al. 1998) and from R A Maurer (Day \& Maurer 1989) respectively. All reporter constructs were confirmed by sequencing and then purified using a Plasmid Midi Kit (Qiagen).

\section{Cell culture and transient transfection assay}

Human cervical carcinoma (HeLa), human embryonic kidney cells (HEK-239), IMR-32 (human neuroblastoma), TIG-1 (human normal diploid fibroblast; Ohashi et al. 1980), and NS20Y and Neuro2A (mouse neuroblastoma cells) were grown in Dulbecco's modified Eagle's medium (DMEM) containing 10\% fetal calf serum (FCS). T47D (human breast cancer cells) were grown in RPMI-1640 medium supplemented with $10 \%$ FCS. $\mathrm{GH}_{3}$ cells were grown in F-10 medium containing 2.5\% FCS and $15 \%$ horse serum. All cells were maintained in humidified $5 \% \mathrm{CO}_{2}-95 \%$ air at $37^{\circ} \mathrm{C}$. Cells were seeded in a 24-well tissue culture plate $24-48 \mathrm{~h}$ prior to transfection. Transient transfection experiments were carried out using Lipofectamine Plus reagent (Invitrogen Co.; Kimura et al. 2001). Plasmids expressing Renilla luciferase such as pRL-TK or pRL-CMV were used as internal controls to normalize varying transfection efficiencies. For studies of estrogen action, cells were grown in phenol red-free DMEM containing charcoaltreated sera and the transfection was performed using phenol red-free OPTI-MEM. SL2 cells (a generous gift from S Ohsako (TMIN, Tokyo, Japan)) were grown in Schneider's medium containing $10 \%$ FCS at $25^{\circ} \mathrm{C}$. SL2 cells $\left(2-4 \times 10^{6}\right.$ cells per a well $)$ were plated onto a 24-well tissue culture plate. After 2 days of seeding, the cells were transfected with $400 \mathrm{ng}$ reporter plasmids, $4 \mathrm{ng}$ of an internal standard plasmid (pRL-CMV), and 50 ng pPac0, pPacSp1, pPacSp2, or pPacSp3 expression vector. $\mathrm{pPac} 0$ is an empty vector which does not express $\mathrm{Sp}$ proteins. Cells were harvested $48 \mathrm{~h}$ after the transfection and luciferase activities in the cell lysate were assayed. The promoterless pGL3-Basic vector was included as a control in the transfection experiments and the results of the luciferase activity were calculated relative to the activity of pGL3-Basic.

\section{Electrophoretic mobility shift assay (EMSA)}

EMSA was performed as described previously (Kimura et al. 2001). In brief, ${ }^{32} \mathrm{P}$-labeled probe A $(-107 /-26)$, probe $\mathrm{B}(-65 /-26)$, and probe $\mathrm{E}(-388 /-326)$ were 
A

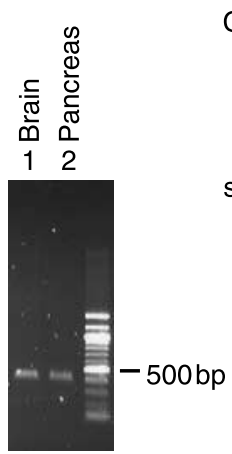

B

h

$\mathrm{m}$

$\mathrm{h}$

r

m

$\mathrm{h}$

m

h

$\mathrm{r}<$

$\mathrm{m}$

$\mathrm{m}$

h

r

$\mathrm{m}$

h

$r$

m

h

m

h

r

$\mathrm{m}$

h

r

h gtgtgt<

m gtgcgt<

h gccaatcttcctctttccttccagATGTCACACTGGATCCTTGGCCTCCAGGGTCCATT

$r$ ttaccttttctgcttctttcccagATGTCACGATAGACCCTTGGCC-CCAGAGTCCACT

$\mathrm{m}$ ctacttettctgcttcttttcccagATGTCACAGTAGACTCTTGGCCCCCAGAGCCCTGT

h AAGGTGAGAATAAGATCTCTGGGCTGGCTGGAACTAGCCTAAGACTGAAAAGCAGCCATG

r GAGGTGAGAGGAAGATCTCTGGGCTGCTTGGTTCTAGGCG--GACTGAAGAGCAGCCATG

$\mathrm{m}$ GAGGCGAGAGGAAGATCTCTAGGCAGCTTGGTTCTAGACG--GAGTGGAAAGCAGCCATG

C

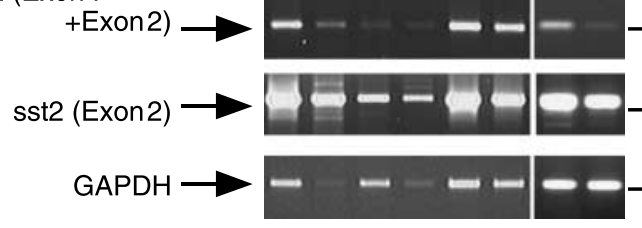

$356 \mathrm{bp}$

$561 \mathrm{bp}$

$450 \mathrm{bp}$

$-350$

$-290$

$-120$

$+275$

$+4180$

$+4240$

$+4300$

www.endocrinology-journals.org 
prepared using a Klenow fragment of DNA polymerase. For probe $\mathrm{C}(-79 /-50)$ or probe $\mathrm{D}(-99 /-73)$, oligonucleotides (S2-8 and S2-9 or S2-10 and S2-11 respectively) were synthesized as overhanging complementary strands, annealed, purified by high performance liquid chromatography (HPLC), and end-labeled with $\left[\alpha^{-32} \mathrm{P}\right]$ deoxy-CTP. Nuclear extracts $(2 \cdot 5-3 \cdot 0 \mu \mathrm{g})$ or purified ER proteins were added to the binding reaction mixture, preincubated with or without DNA competitors at $4{ }^{\circ} \mathrm{C}$ for $30 \mathrm{~min}$, and then the labeled probes were added. In supershift experiments, antibodies $(1.5 \mu \mathrm{g})$ obtained from Santa Cruz Biotechnology Inc. were added to a reaction mixture prior to addition of the probes. Incubation was performed for $20 \mathrm{~min}$ at $22^{\circ} \mathrm{C}$, then overnight at $4{ }^{\circ} \mathrm{C}$. The reaction mixture was loaded onto a $4 \%$ native polyacrylamide gel in $0.5 \times \mathrm{TBE}$ and run at $150 \mathrm{~V}$. The gels were dried and analyzed using a FUJIX Bio Imaging Analyzer, BAS2000 (Fuji Photo Film Co. Ltd, Tokyo, Japan).

\section{Chromatin immunoprecipitation (ChIP) assay}

The ChIP assay was performed using a Chip-IT kit (Active Motif Japan, Tokyo, Japan) according to the manufacture's instruction. In brief, after treatment of estrogen, cells were fixed with $1 \%$ formaldehyde for $10 \mathrm{~min}$ at room temperature and the fixation was stopped with Glycine Stop-Fix solution. Then cells were lysed in lysis buffer and centrifuged to obtain chromatin fraction. The chromatin was suspended in a Shearing Buffer, sonicated to shear DNA (a shearing DNA size of $\sim 300-600 \mathrm{bp}$ ) with a handy sonic (Tomy Seiko Co. Ltd, Tokyo, Japan), and then pre-cleaned with protein G beads. These samples were immunoprecipitated overnight at $4{ }^{\circ} \mathrm{C}$ with specific antibodies to the N-terminal domain of ER $\alpha$ (H-184) or ER $\beta$ (H-150; Santa Cruz Biotechnology Inc). The complexes of antibody and chromatin were collected with protein $G$ beads, followed by extensive washing. For reverse of crosslinks between protein and DNA, the immune complexes were incubated at $65^{\circ} \mathrm{C}$ overnight. After proteinase $\mathrm{K}$ digestion, DNA was purified using DNA purification mini-column. The purified DNAs were analyzed by PCR (31 cycles) using primer sets of S2-12 and S2-13, and S2-14 and S2-15 to amplify $-457 /-276$ region and $+968 /+1121$ region of the human sst 2 gene respectively. PCR products were resolved on a $2.5 \%$ ethidium bromide-agarose gel and densitomeric quantification was performed with an ATTO densitograph (ATTO Ltd, Tokyo, Japan).

\section{Statistical analysis}

Results are shown as the mean \pm s.E.M. of at least three independent transfection experiments. On each transfection experiment, each sample was assayed in triplicate or quadruplicate. The significance of difference was determined by Student's $t$-test. $P<0 \cdot 05$ was considered as statistically significant.

\section{Results}

\section{Structure of the $5^{\prime}$-flanking region of the human sst2 gene}

During the course of studies on the transcriptional regulation of the human sst2 gene, we found another exon in the $5^{\prime}$-upstream region (Kimura \& Takamatsu 2002), which was followed by verification by MGC Program Team (Strausberg et al. 2002). To determine the transcription initiation site of the human sst 2 gene, $5^{\prime}$-end of the cDNA obtained from total RNAs of normal human brain and pancreas was first analyzed. When PCR was performed to amplify sst2 cDNA linked to SMART oligonucleotide at the $5^{\prime}$-end, a single band ( $\sim 400 \mathrm{bp}$ ) was obtained from both the tissues (Fig. 1A). From analyses of these bands, $5^{\prime}$-end of the sst2 transcripts was found to be located at +12 of the human sst2 mRNA sequence of the MGC program team (Fig. 1B). The results demonstrated that the $5^{\prime}$-UTR of human sst2 gene is in fact composed of two exons and that the newly identified exon 1 is transcribed in various cultured cells of human origin as well, including HeLa, HEK-239, IMR-32 neuroblastoma, TIG-1 normal diploid fibroblast, and T47D breast cancer cells (Fig. 1C).

\begin{abstract}
Figure 1 Identification of the transcription initiation site of the human sst2 gene. (A) The total RNAs from human brain and pancreas were reverse transcribed in the presence of the SMART II oligonucleotide and then PCR and the nested PCR were performed. The PCR products were separated on ethidium bromide-agarose gel (Lanes 1 and 2). In all clones containing the specific $5^{\prime}$-sequence of the sst2 gene (9 clones from the brain and 12 clones from the pancreas), the start site was located 349 nucleotides upstream from the ATG codon. (B) Nucleotide sequence of the human sst2 gene (h). Regions of the exon are shown in uppercase letters. The $5^{\prime}$-flanking region and the intron are shown in lowercase letters. The nucleotide numbering starts with +1 at the transcription initiation site of the MGC team (GenBank accession number NM001050). The initiation site that we determined in the present study is shown as an arrow $(+12)$. Sequence motifs described in the text are marked with bold lines. The translation start site, ATG, is boxed. The promoter region and exon 1 of the rat (DDBJ accession number AB047297; r) and mouse sst2 genes (DDBJ accession number AJ005519, AJ005520; $m$ ) are given in parallel. Conserved nucleotides are indicated with asterisks $\left(^{*}\right) .(C)$ Transcriptional expression of the sequence containing exons 1 and 2 of the sst2 in various human-cultured cell lines along with human tissues. PCR amplification was performed using primers of sense exon 1- and antisense exon 2-specific oligonucleotides (upper panel), the specific primers of exon 2 (middle panel), and primers of GAPDH (bottom panel).
\end{abstract}


Next, to study molecular mechanism of the transcriptional control of sst 2 gene, we cloned a $5^{\prime}$-upstream region from the translation initiation site (8031 bp, GenBank accession number AB260891). It was composed of $5^{\prime}$-flanking region ( $3745 \mathrm{bp}$ ), exon 1 ( $257 \mathrm{bp}$ ), intron (3937 bp), and exon 2 (92 bp). Proximal upstream region of the transcription initiation site did not contain typical TATA and CCAAT boxes. Upstream sequence $(100 \mathrm{bp})$ of the transcription initiation site resembled those of rat and mouse genes with about $75 \%$ homology, demonstrating that the structure of the $5^{\prime}$-flanking region of sst 2 gene is conserved between human and rodent species (Fig. 1B).

\section{Functional analysis of the $5^{\prime}$-flanking region of the human sst2 gene}

To examine promoter activity of the $5^{\prime}$-flanking region of the exon 1, the region with various lengths was linked to a firefly luciferase reporter gene in a pGL3-Basic vector. The constructs were then transfected into human-cultured HeLa or T47D cells, rat pituitary $\mathrm{GH}_{3}$ cells, and mouse neuroblastoma NS20Y and Neuro2A cells (Fig. 2A). Constructs containing the proximal $5^{\prime}$-flanking region of exon $1(-3734 /+149 /$ luc, $-111 /+149 /$ luc,$\quad-325 /+4297 /$ luc) generally provided strong promoter activity when compared with those lacking the region $(+478 /+4297 /$ luc, $+4167 /+4297 /$ luc $)$. It should be emphasized that the promoter activity of $-111 /+149 /$ luc construct was much stronger than that of $+4167 /+4297 /$ luc construct containing the SSTR2inr region (Pscherer et al. 1996). The promoter activity of $-325 /+4297 /$ luc construct was higher in HeLa and T47D cells (1.6- to $1 \cdot 7$-fold) than those of $-111 /+149 /$ luc construct, whereas it showed lower level in other cells tested, including HEK-293 and IMR-32 (data not shown), suggesting the existence of a transcription enhancing
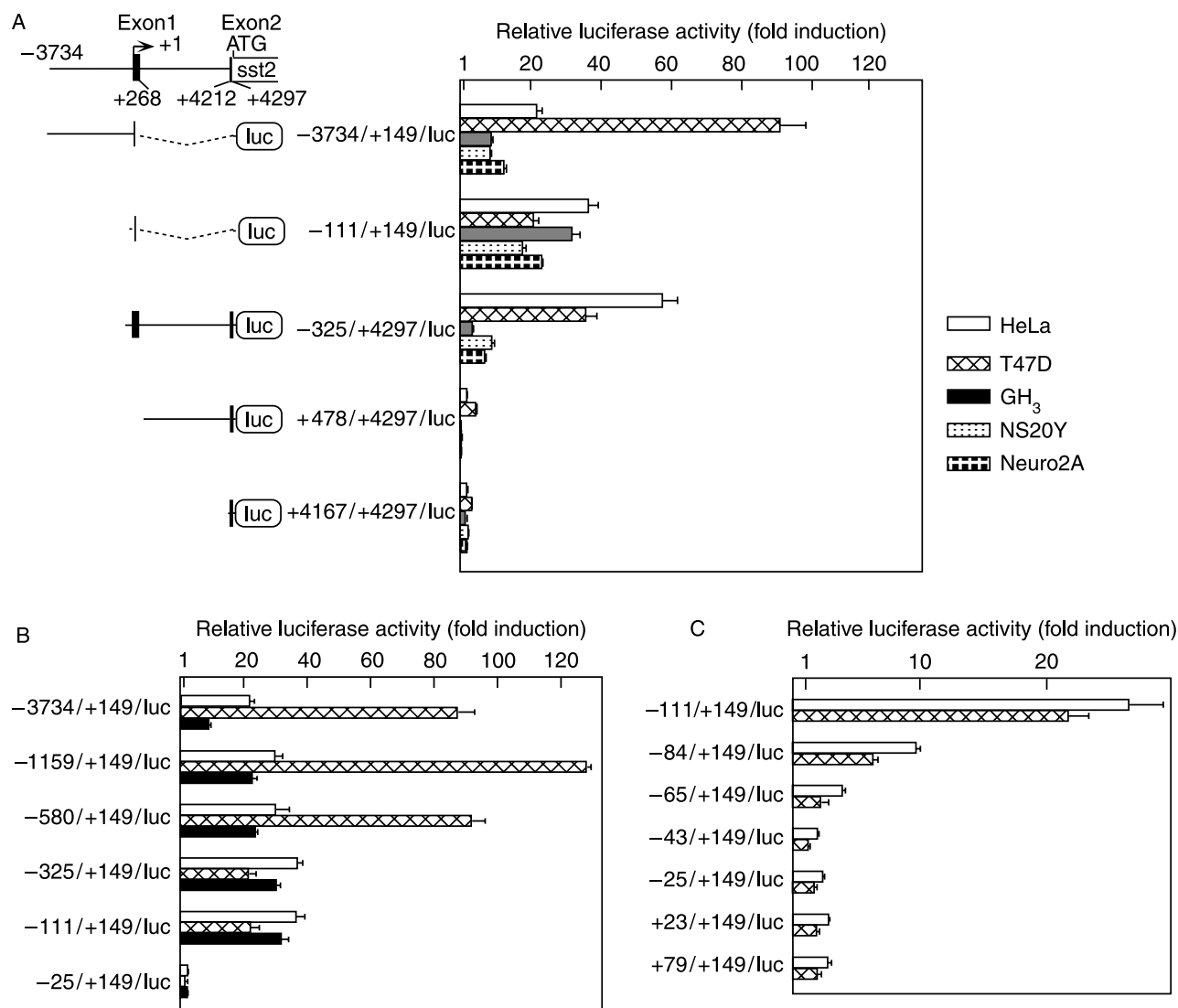

Figure 2 Promoter activity of the $5^{\prime}$-flanking region of exons 1 and 2 of the human sst2 gene. (A) Cultured cell lines were transfected with plasmids containing various reporter gene constructs together with a Renilla luciferase expression plasmid (pRL-CMV) as an internal control. Left panel shows plasmid constructs fused to the reporter gene. (B) HeLa, T47D, and $\mathrm{GH}_{3}$ cells were transfected with plasmids containing $5^{\prime}$-flanking region of exon 1 and its deleted mutants. (C) The promoter activities of the plasmids with shorter $5^{\prime}$-upstream regions were determined in HeLa and T47D cells. The relative luciferase activity for each construct, whose amount in molecule was adjusted to that corresponding to the promoterless plasmid (pGL3-Basic), was calculated relative to the activity of pGL3-Basic. 
factor(s) acting on the intron region in HeLa and T47D cells.

The constructs containing $5^{\prime}$-flanking region with various length from -3734 to -25 were further analyzed to identify the region responsible for promoting transcription (Fig. 2B). The promoter activity of $-3734 /+149 /$ luc construct in HeLa, T47D, and $\mathrm{GH}_{3}$ cells showed a 22-, 87-, and 9-fold increase respectively over promoterless plasmid pGL3-Basic. In HeLa and $\mathrm{GH}_{3}$ cells transfected with constructs containing $5^{\prime}$ deleted promoter regions to various extent (from -3734 to -111 ), the promoter activity was further increased. In T47D cells, however, $5^{\prime}$-deletion of the region between -580 and -325 rather caused a remarkable decrease, suggesting that some transcription enhancing factor(s) may act between -580 and -325 . The promoter activity of $-25 /+149 /$ luc only showed a twofold increase in all these cells, making it likely that major regulatory cis-elements of the human sst 2 gene exist between -111 and -25 . Therefore, the construct containing the region from -111 to +149 was practically considered to be a minimal promoter of the human sst2 gene in this study.

To identify possible cis-elements in the region from -111 to +149 , six 5'-deleted constructs, starting from $-84,-65,-43,-25,+23$, and +79 , were tested in
HeLa and T47D cells (Fig. 2C). The regions between -111 and $-84,-84$ and -65 , and -65 and -43 appeared to contain transcription-activating elements.

\section{Determination of trans-acting factors by EMSA}

EMSA was performed to clarify binding factors interacting with the minimal promoter (Fig. 3). Radiolabeled probe $\mathrm{A}(-107 /-26)$ formed three bands $(\mathrm{a}, \mathrm{b}$, and $\mathrm{c})$ with HeLa nuclear proteins (Fig. 3, lane 2). These radioactive bands were displaced with an excess doublestranded oligonucleotide, $-99 /-77$ (lane 3 ) or $-59 /-$ 39 (lane 5), and Sp1 consensus oligonucleotide (lane 6), indicating that each band was composed of the radiolabeled probe and Sp1 family proteins. Radiolabeled probe B $(-65 /-26)$ containing the proximal Sp1 site (Sp1-I) formed bands d, e, and f (lane 8). Band d was supershifted mostly by the addition of anti-Sp1 (lane 9) and in part by the addition of anti-Sp2 (lane 10), whereas the bands $e$ and $f$ were supershifted by the addition of anti-Sp3 antibody (lane 11). For the distal Sp1 site (Sp1II), radiolabeled probe $\mathrm{D}(-99 /-73)$ produced bands $\mathrm{i}, \mathrm{j}$, and $\mathrm{k}$ (lane 24). These bands were supershifted by the addition of antibodies of Sp1, Sp2, and Sp3 (lanes 2527). An antibody against Sp4 did not affect the mobility of the radiolabeled complexes related to Sp1-I and

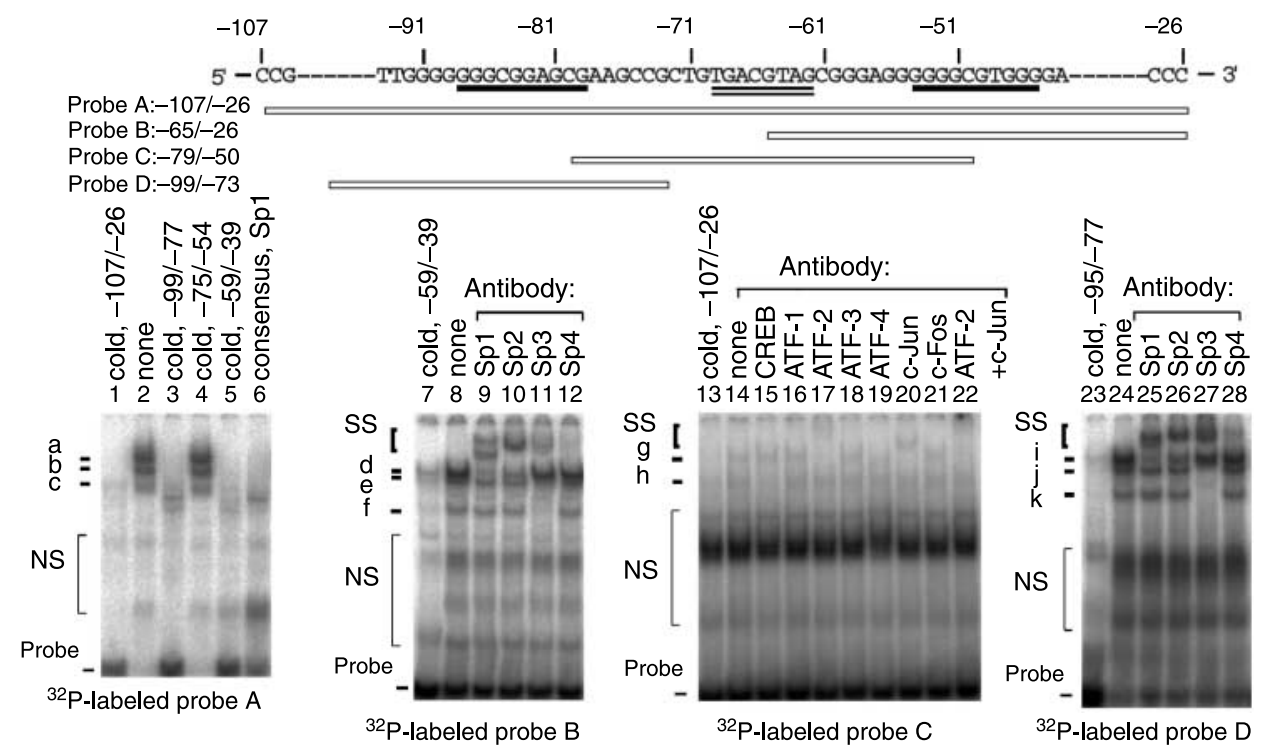

Figure 3 Analysis of the proximal promoter region of the human sst2 gene by EMSAs. The sequence of the relevant part from -107 to -26 containing two Sp1 sites (underline) and an ATF/CRE site (double underline) is shown in the upper panel and probes shown were used. The nuclear extract from HeLa cells was incubated with a ${ }^{32} \mathrm{P}$-labeled probe $\mathrm{A}$ in the absence and presence of $50 \mathrm{ng}$ cold double-strand oligonucleotide $-107 /-26,-99 /-77,-75 /-54$, or $-59 /-39$, and $40 \mathrm{ng}$ consensus double-strand oligonucleotide of Sp1 (lanes 1-6). NS shows nonspecific bands. In lanes 7-12, nuclear extracts from HeLa cells were preincubated without or with anti-Sp1, anti-Sp2, anti-Sp3, and anti-Sp4 before addition of the radiolabeled probe $\mathrm{B}$. In lanes 13-22, nuclear extracts from $\mathrm{GH}_{3}$ cells were preincubated without or with antibodies against members of transcription factors that interact with the CRE motif and then incubated with a radiolabeled probe $C$. In lanes 23-28, nuclear extracts from HeLa were preincubated without or with anti-Sp1, anti-Sp2, anti-Sp3, and anti-Sp4 before addition of a radiolabeled probe D. 
Sp1-II (lanes 12 and 28) although Sp4 is known to express in the brain and in certain cell lines including HeLa cells (Hagen et al. 1992). Concerning a putative ATF/CRE site, any radioactive bands formed with the radiolabeled probe A were not displaced with excess double-stranded oligonucleotide $-75 /-54$ (lane 4). However, when we employed probe $\mathrm{C}(-79 /-50)$ containing only a putative ATF/CRE site, two bands (g and $\mathrm{h}$ ) were observed (lane 14), both of which were competed with excessive amounts of $-107 /-26$ (lane 13). Anti-ATF-2 and anti-c-Jun antibodies supershifted band $\mathrm{g}$ (lanes 17, 20, and 22), but antibodies against ATF-1, ATF-3, ATF-4, and c-Fos did not. Anti-CREB abolished band $\mathrm{h}$ (lane 15). These results demonstrate that Sp1, Sp2, and Sp3 bind to the Sp1-I and Sp1-II sites in the minimal promoter, whereas ATF-2, c-Jun, and CREB bind to the ATF/CRE site.

\section{Determination of cis-elements by mutagenesis analysis}

To evaluate two Sp1 motifs (Sp1-I and Sp1-II sites) and one ATF/CRE motif, mutations were introduced within the minimal promoter and their promoter activities were examined (Fig. 4). Sp1-I and Sp1-II sites of the wild-type plasmid (WT1, $-111 /+149 /$ luc) were mutated from GGGGCGTGGG to GGTTCGTGGG and GGGCGGAGCG to GTTCGGAGCG (Mut1 and Mut3) respectively. Mutation of Sp1-I (Mut1) reduced the promoter activity to $49 \%$ of that of WT1 in HeLa cells, but such reduction was not observed in T47D and $\mathrm{GH}_{3}$ cells. Mutation of Sp1-II (Mut3) caused profound decrease in HeLa, T47D, and $\mathrm{GH}_{3}$ cells. When the ATF/CRE site was mutated from TGACGTAG to TGTGGTAG (Mut2), the promoter activity decreased comparable with those of Mut3. Double mutations of Sp1-II together with either Sp1-I or ATF/CRE (Mut5 and Mut6) produced more decrease than Mut3, whereas double mutation of Sp1-I and ATF/CRE (Mut4) did not show such further decrease. Triple mutation (Mut7) led to the largest suppression to $<10 \%$ of WT1. From these data, it appears that Sp1-II works predominantly over the other sites to activate the promoter activity and acts cooperatively with ATF/CRE site. Sp1-I also showed such cooperativity with
ATF/CRE

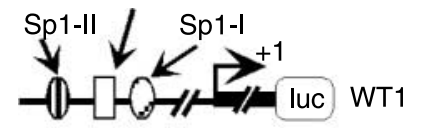

(WT1:-111/+149/luc)
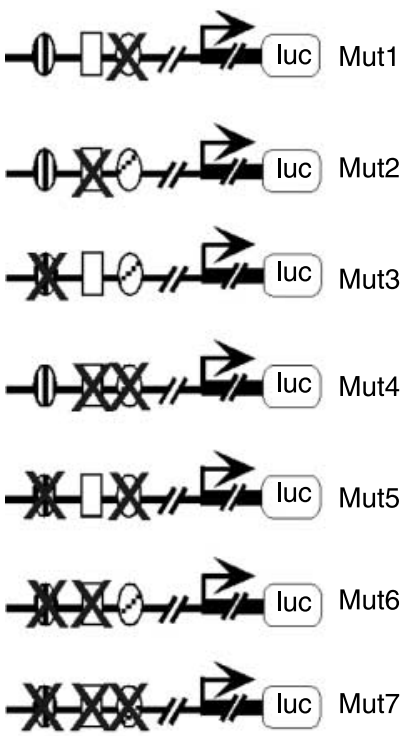

Relative luciferase activity

(\% of control)

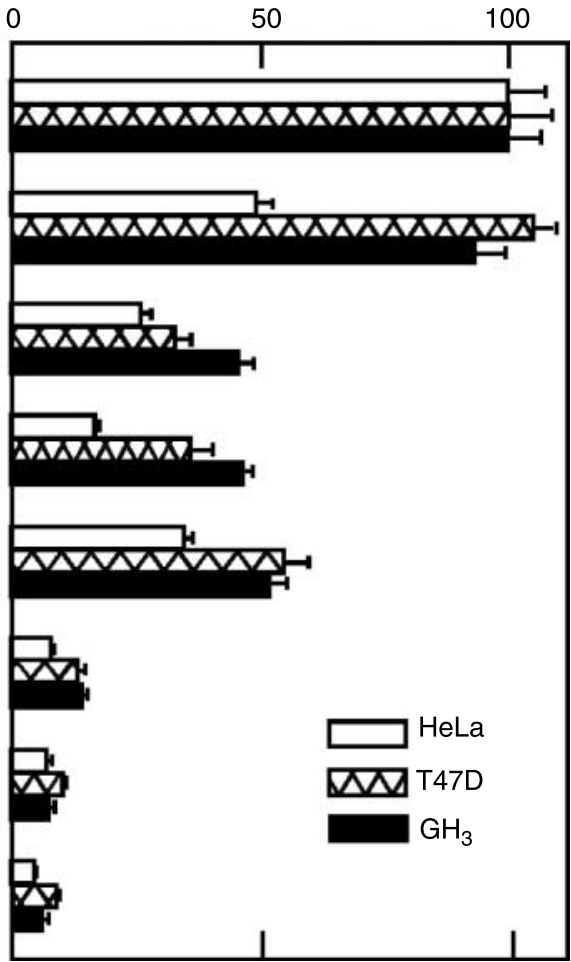

Figure 4 Requirement of Sp1-I, Sp1-II, and ATF/CRE sites for the full promoter activity of the human sst2 gene. Schematic representation of the human sst2 reporter construct (WT1: $-111 /+149 / \mathrm{luc}$ ) and its mutated ones (Mut1-7) is shown in the left panel. The mutated sites are indicated as $X$. These constructs were transfected into HeLa, T47D, and $\mathrm{GH}_{3}$ cells. The relative luciferase activity is given as a percentage of the activity of the wild-type construct. 
ATF/CRE site. These results indicate that Sp1-I, ATF/ CRE, and Sp1-II sites appear to play essential roles in expressing the human sst2 promoter activity.

\section{Identification of Sp1-related proteins trans-acting on the proximal promoter in Sp-deficient Drosophila cells}

The finding that the promoter activity of Mut1 construct decreased in HeLa cells with no change in T47D and $\mathrm{GH}_{3}$ cells led us to examine the effects of Sp family proteins using Drosophila SL2 cells deficient in endogenous Sp1-related proteins (Suske 1999). The promoter activity of $-25 /+149 /$ luc construct lacking both Sp1 sites increased 2.1-fold by expressing Sp1 with pPacSp1, whereas $-75 /+149 /$ luc construct containing Sp1-I site resulted in further increase (3.0fold; Fig. 5). Cotransfection of pPacSp1 and $-111 /+$ 149/luc construct containing both Sp1-I and Sp1-II sites caused an additional increase (4.3-fold) in the reporter activity. Both pPacSp3 and pPacSp2 were capable of enhancing the promoter activity of $-111 /+149 /$ luc construct $2 \cdot 3$ - and $1 \cdot 8$-fold respectively, but this enhancement was lost for $-25 /+149 /$ luc and $-75 /+149 /$ luc constructs. It follows that the Sp1-I site is preferentially used for transactivation by $\mathrm{Sp} 1$ protein, while the Sp1-II site is available for Sp3, Sp1, and Sp2 proteins. In addition, the data suggested an unidentified cis-regulatory site responsible for Sp1 between -25 and +149 of the human sst 2 gene.

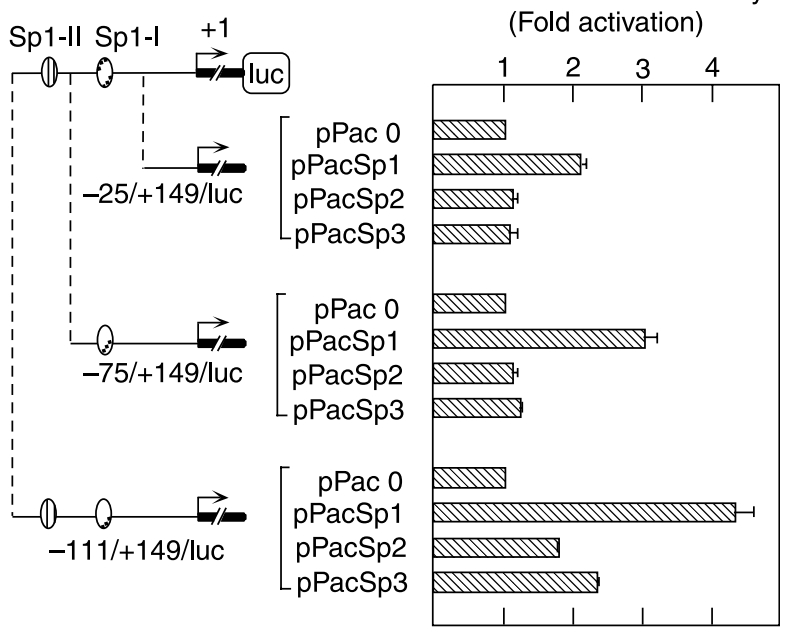

Figure 5 Effect of overexpression of Sp1, Sp2, and Sp3 on the promoter activity of the human sst2 gene in Drosophila SL2 cells. Drosophila SL2 cells were transfected with indicated reporter constructs together with either of the expression plasmids pPacSp1, pPacSp2, and pPacSp3 as described in Materials and methods. The relative luciferase activity is given as a fold activation over each value obtained with the empty vector of pPac0.

\section{Activation of the promoter activity of human sst2 gene by estrogen}

The mRNA expression of the human sst2 gene as well as rat one is under the regulation by estrogen (Xu et al. 1996, Kimura et al. 1998, Hofland \& Lamberts 2003). Since $17 \beta$-estradiol $\left(\mathrm{E}_{2}\right)$ up-regulates mRNA level of the rat sst2 gene in $\mathrm{GH}_{3}$ cells (Kimura et al. 2001), $\mathrm{E}_{2}$ action on the promoter activity was investigated using $\mathrm{GH}_{3}$ cells first. $\mathrm{E}_{2}$ increased the reporter activity of $-3734 /+149 /$ luc construct (Fig. 6A). The activation by $\mathrm{E}_{2}$ was observed even after the $5^{\prime}$-region was deleted up to -111 , but $\mathrm{E}_{2}$ caused suppression for $-25 /+$ $149 /$ luc construct $(P<0 \cdot 05)$. Promoter activity of $-325 /+4297 /$ luc $(1 \cdot 24$-fold increase $)$ showed no major difference compared with that of $-111 /+149 /$ luc construct $(1 \cdot 31$-fold increase) with respect to the transcriptional activation by $\mathrm{E}_{2}$ (Fig. $6 \mathrm{~A}$ ). The results implied that the region between -111 and +149 of the human sst 2 gene was sufficient for the $\mathrm{E}_{2}$ responsiveness in $\mathrm{GH}_{3}$ cells but the extent of activation by $\mathrm{E}_{2}$ was relatively low compared with that observed for the rat counterpart region (Kimura et al. 2001).

Next, we analyzed the estrogen effect on the promoter activity of the human sst 2 gene using T47D breast cancer cells, which express ER $\alpha$ and, to a lesser extent, ER $\beta$ (Kietz et al. 2004). In T47D cells, $\mathrm{E}_{2}$ treatment for $24 \mathrm{~h}$ increased sst2 transcript containing the exon 1 by threefold (Fig. 6B), demonstrating at least that most of the estrogen-induced transcription of sst2 mRNA occurs upstream of the exon 1 . When T47D cells were transfected with $-3734 /+149 /$ luc construct, promoter activity was activated by $\mathrm{E}_{2}$ up to $3 \cdot 7$-fold (Fig. 6C). This activation was decreased by deleting from -3734 to -325 . Both $-325 /+149 /$ luc and $-111 /+149 /$ luc constructs still responded to $\mathrm{E}_{2}$ but $-25 /+149 /$ luc construct did not (Fig. 6C). These results make it likely that there are at least two $\mathrm{E}_{2}$-responsive regions in the proximal and distal parts of the promoter. An ER antagonist ICI182780 by itself did not show any effect on the reporter activity of $-3734 /+149 /$ luc at $10^{-7} \mathrm{M}$ and $10^{-6} \mathrm{M}$, and almost completely abolished the activation by $\mathrm{E}_{2}\left(10^{-8} \mathrm{M}\right)$ at a concentration of $10^{-6} \mathrm{M}$ (Fig. 6D). In an experiment shown in Fig. 6E, where ICI182780 was included in the $\mathrm{E}_{2}$-untreated group to minimize possible contamination by estrogen-like substance(s), estrogen responsiveness was unchanged until $5^{\prime}$-upstream was shortened up to -463 but drastically declined in more deleted constructs (Fig. 6E, right panel). The region between -1159 and -464 appears to contain estrogen-independent transcriptional enhancing elements (Fig. 6E, left panel). Therefore, the region between -463 and -427 seemed to be responsible for the distal transcriptional activation by estrogen.

Tamoxifen, which is known as an anti-estrogen in the breast cancer therapy (Jordan \& Morrow 1999), also 
activated the promoter activity of $-580 /+149 /$ luc (1.9-fold increase), although the increase by tamoxifen was lower than that by $\mathrm{E}_{2}$ (Fig. $6 \mathrm{~F}$ ).

Meanwhile, in HeLa cells overexpressing ER $\alpha$, the promoter activity of $-580 /+149 /$ luc construct was increased only by $30 \%$ with $\mathrm{E}_{2}$ treatment, whereas under similar conditions $\mathrm{E}_{2}$ addition resulted in 3.7fold increase for a construct consisting of SV40 promoter and PRL enhancer region containing ERE (Klinge 2001; Fig. 6G). It follows that estrogen responsiveness of the distal region of the human sst2 gene may take place in a cell-specific manner.
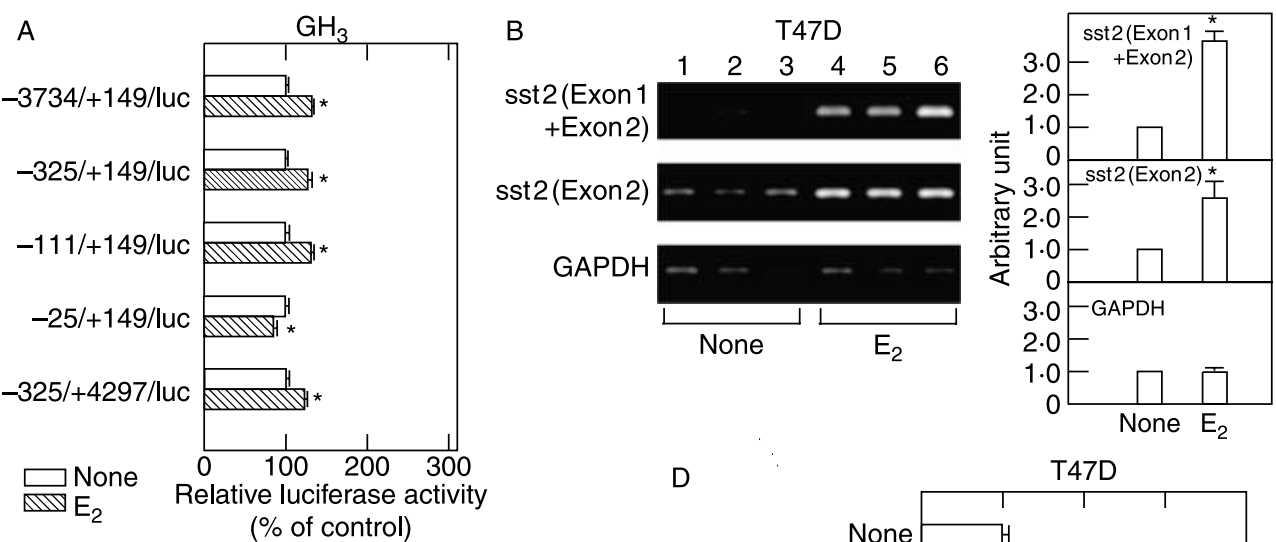

(\% of control)
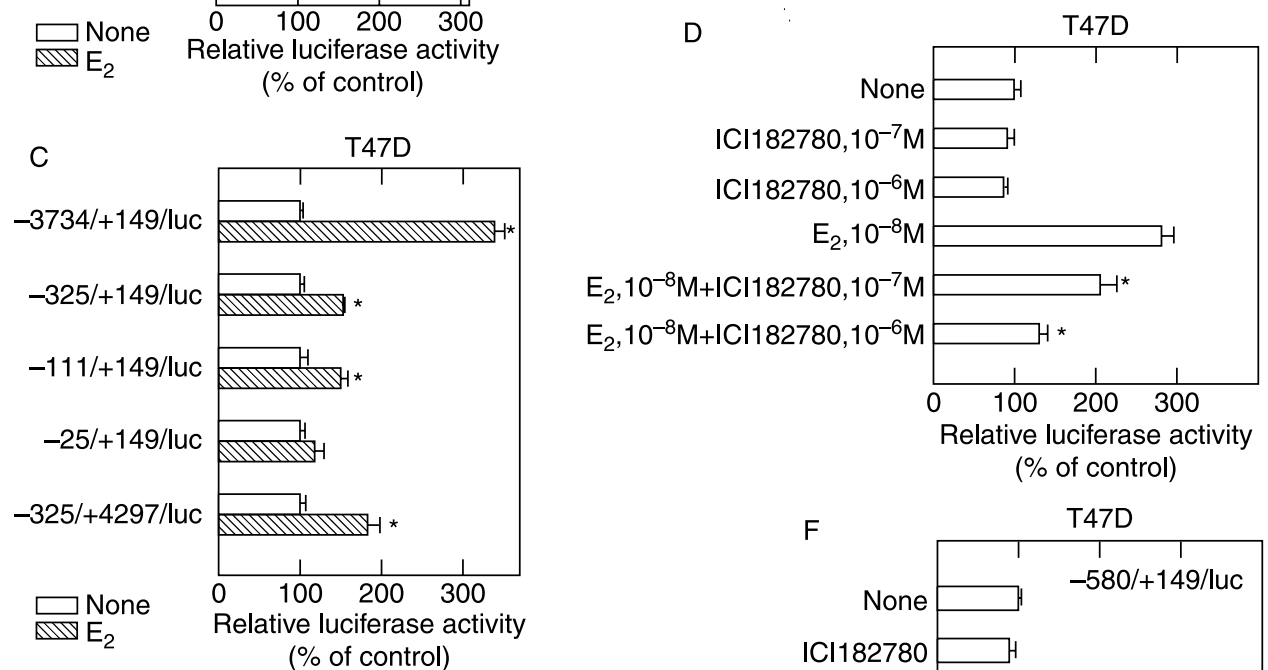

E

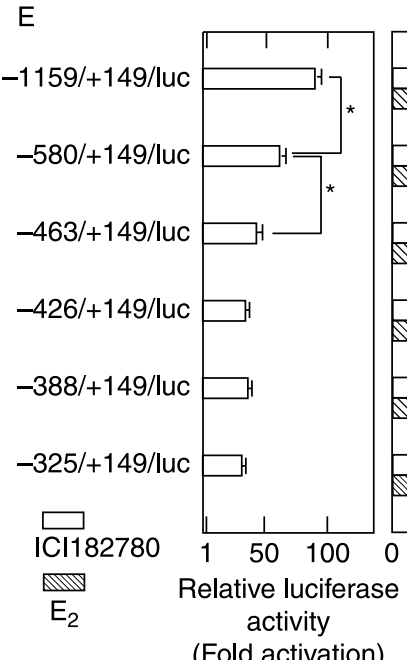

(Fold activation)

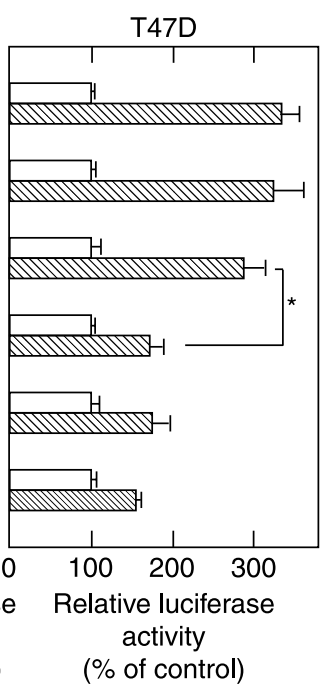

(\% of control)

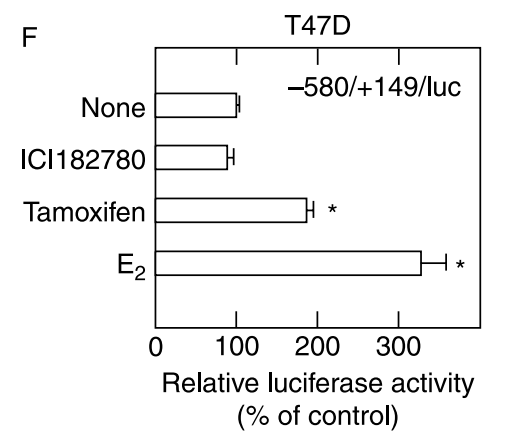

G

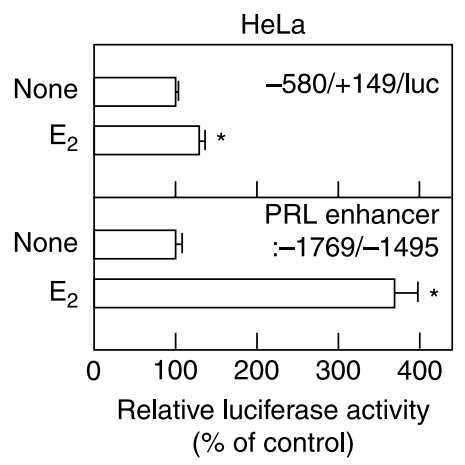




\section{Determination of estrogen-responsive cis-elements by mutagenesis analysis}

The proximal $\mathrm{E}_{2}$ responsiveness was lost in $-111 /+$ 149/luc constructs mutated at either ATF/CRE (Mut2) or Sp1-II (Mut3) site (Fig. 7A). Mutation of Sp1-I (Mut1) also affected the activation by $\mathrm{E}_{2}$ in T47D cells but not in $\mathrm{GH}_{3}$ cells. Double mutations of ATF/CRE and Sp1-II rather resulted in suppression when compared with the control group. Thus, these proximal cis-elements, either one or in concert, are likely to mediate the transcriptional activation by $\mathrm{E}_{2}$.

On the other hand, as to the distal $\mathrm{E}_{2}$ responsiveness, all of the cis-elements of the minimal promoter, namely Sp1-I, ATF/CRE, and Sp1-II, were required in T47D cells, although the minimum estrogen responsiveness was observed $(\sim 1 \cdot 5$-fold increase) with mutation in each cis-element (Fig. 7B). Therefore, the distal estrogen-responsive region may act like an enhancer for the minimal promoter. The region between -463 and -427 was further analyzed using WT2 $(-580 /+149 /$ luc $)$ and its deleted constructs. Deletion of AT-rich sequence between -463 and -448 (Mut8) or GC-rich sequence between -447 and -431 (Mut9) did not affect the $\mathrm{E}_{2}$ responsiveness (Fig. 7C). However, the $\mathrm{E}_{2}$ responsiveness declined to some extent by deleting another GC-rich sequence between -430 and -414 (Mut10) and decreased further to the proximal $\mathrm{E}_{2}$ response level in a construct deleted between -447 and -414 (Mut11). Therefore, the $-447 /-414$ GC-rich region was found to be strictly required for the distal $E_{2}$ responsiveness.

\section{Role of ERE half-site and ER $\alpha$ for distal $E_{2}$ responsiveness in T47D cells}

To further investigate the molecular basis for the distal $\mathrm{E}_{2}$ responsiveness produced by the $-447 /-414$ GC-rich region, we explored potential responsible sequences. No typical ERE known as GGTCA(N) 3 TGACC (Klinge 2001) was present between -580 and +149 , but one half-site (GGTCA) of ERE was detected between -348 and -344 . In proximity to the half-site, one imperfect ERE half-site with one nucleotide variation (-366/-362, GGTCC) was located like DR12, which was the direct repeat of the ERE half-site (AGGTCA) separated by 12 nucleotides (Klinge 2001). Therefore, whether these sequences are relevant was tested using a construct with deletion of these ERE halfsites (Mut12). Mut12 showed decreased promoter activity in T47D cells (Fig. 8A). Moreover, mutation of the half ERE (from GGTCA to GTACA, Mut13) alone caused a decrease. Neither of these reductions occurred in $\mathrm{GH}_{3}$ cells. Mutation of the imperfect half ERE (GGTCC to GTACC) did not affected the promoter activity (data not shown).

When either $\operatorname{ER} \alpha$ or $\operatorname{ER} \beta$ was overexpressed, the promoter activity of WT2 was potentiated in T47D cells (Fig. 8B). However, this potentiation was lost when Mut13 was used under the same condition. In accordance with these results, EMSA revealed that the recombinant proteins of $\mathrm{ER} \alpha$ and $\mathrm{ER} \beta$ bound to radiolabeled probe $\mathrm{E}(-388 /-326)$ containing the half ERE and formed bands a and b respectively (Fig. 8C, lanes 1 and 6 ). Both bands were completely displaced by excessive amounts of consensus ERE (lanes 4 and 9) and in part by cold oligonucleotides, $-361 /-334$ (lanes 2

Figure 6 Analysis of estrogen action on the promoter activity of the human sst2 gene. $(A)$ Effect of 17 $\beta$-estradiol $\left(E_{2}\right)$ on the promoter activity of the human sst2 gene in $\mathrm{GH}_{3}$ cells. Each construct indicated in the Fig. (300 ng) and pRL-TK (16 ng) was cotransfected into $\mathrm{GH}_{3}$ cells. After transfection, the cells were incubated in the medium with or without $10^{-8} \mathrm{M} \mathrm{E}_{2}$ for $24 \mathrm{~h}$. The relative luciferase activity of the $E_{2}$-treated group is given as a percentage of the control without $E_{2}$. ${ }^{\star} P<0.05$ compared with the value without $E_{2}$. (B) The sst2 mRNA levels were increased by $E_{2}$ in T47D cells. The expression of sst2 transcripts was examined after 24-h treatment without or with $E_{2}\left(10^{-8} \mathrm{M}\right)$ in T47D cells, using RT-PCR as described in the legend of Fig. 1C (left panel). The PCR products were semi-quantified by Atto densitograph soft and date are shown as the mean \pm S.E.M. of three independent experiments (right panel). Each experiment was performed in duplicate or triplicate. ${ }^{*} P<0.05$ compared with the value without $E_{2}$. (C) Effect of $E_{2}$ on the promoter activity of the human sst2 gene in T47D cells. Each construct indicated ( $300 \mathrm{ng})$ was cotransfected with pRL-CMV (0.1 ng) into T47D cells. After transfection, the cells were cultured for $15 \mathrm{~h}$, followed by a $32-\mathrm{h}$ culture in medium containing $10^{-8} \mathrm{M} \mathrm{E}_{2}$. The relative luciferase activity of the $\mathrm{E}_{2}$-treated group is given as a percentage of the control without $\mathrm{E}_{2}$. ${ }^{*} P<0.05$ compared with the value without $\mathrm{E}_{2}$. (D) Inhibition of $\mathrm{E}_{2}$-activated promoter activity by ICI182780. After the cells were transfected with the $-3734 /+$ 149 /luc construct, cells were cultured overnight and then treated without or with $10^{-8} \mathrm{M} \mathrm{E}$ in the presence of $10^{-7} \mathrm{M}$ or $10^{-6} \mathrm{M}$ ICl182780. The relative luciferase activity is given as a percentage of the control without chemicals. ${ }^{*} P<0.05$ compared with the value of $E_{2}$. (E) Effect of $E_{2}$ on the promoter activity of various construct of the human sst2 gene in T47D cells. Each construct was transfected into T47D cells as described in C. In the left panel, the relative luciferase activity of the $10^{-7} \mathrm{M} \mathrm{ICl} 182780$-treated group is shown as fold activation compared with the activity of pGL3-Basic. In the right panel, the relative luciferase activity of the $\mathrm{E}_{2}$-treated group is indicated as percent of that of the ICl182780-treated group. $\left({ }^{\star} P<0 \cdot 05\right)$. (F) The transcriptional activation of the construct $-580 /+149 / \mathrm{luc}$ without or with ICl182780 $\left(10^{-7} \mathrm{M}\right)$, tamoxifen $\left(10^{-7} \mathrm{M}\right)$, and $\mathrm{E}_{2}\left(10^{-8} \mathrm{M}\right)$. The relative luciferase activity is given as a percentage of the control with ethanol as a vehicle. $\left({ }^{\star} P<0.05\right)$. (G) Effect of $E_{2}$ on the promoter activity of the construct $-580 /+$ $149 /$ luc in HeLa cells overexpressed with the ER $\alpha$. The $-580 /+149 /$ luc construct or the pGL3-Promoter vector harboring PRL enhancer ( $-1769 /-1495$ containing ERE; 350-400 ng) was cotransfected with the ER $\alpha$ expression vector (pSV2RcER (20 ng) in the absence or presence of Pit-1 expression vector $(20 \mathrm{ng})$. The relative luciferase activity of $\mathrm{E}_{2}$-treated groups is given as a percentage of the control without $\mathrm{E}_{2}$. ${ }^{\star} P<0.05$ compared with the value of the control without $\mathrm{E}_{2}$. 
A

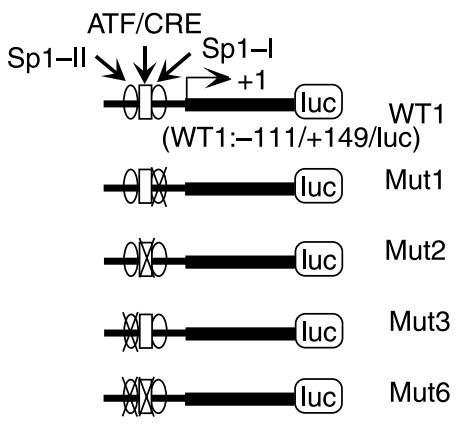

B

C

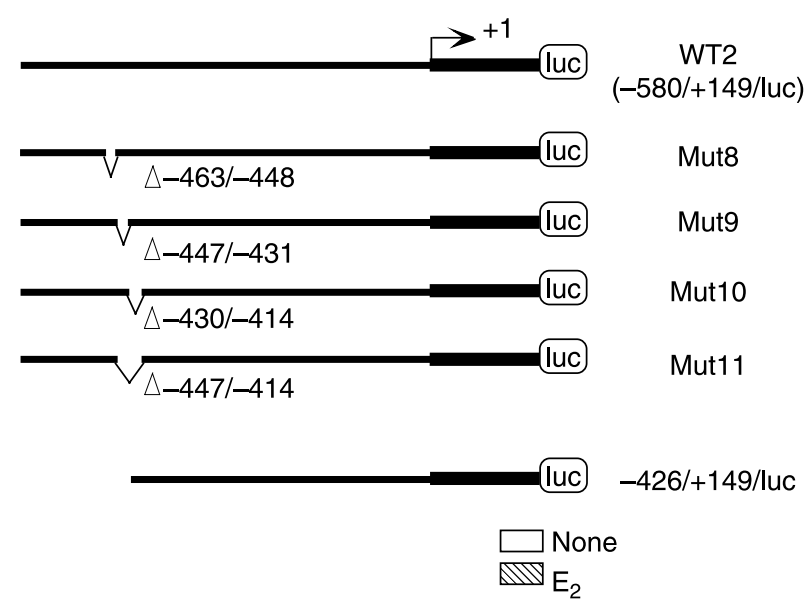

$\square$ ICl182780

$\mathbb{N} E_{2}$

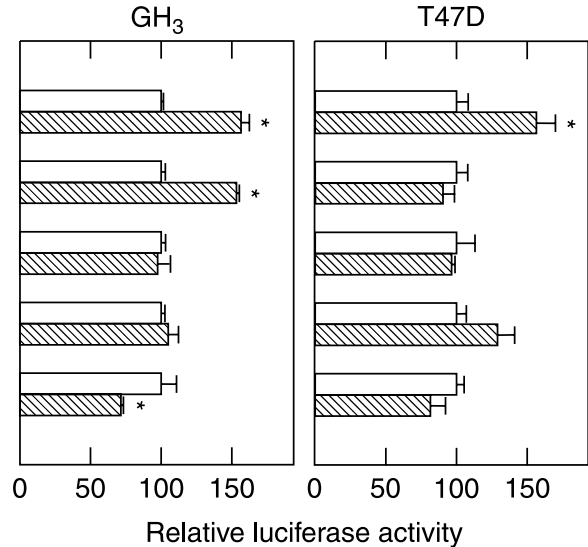

(\% of control)

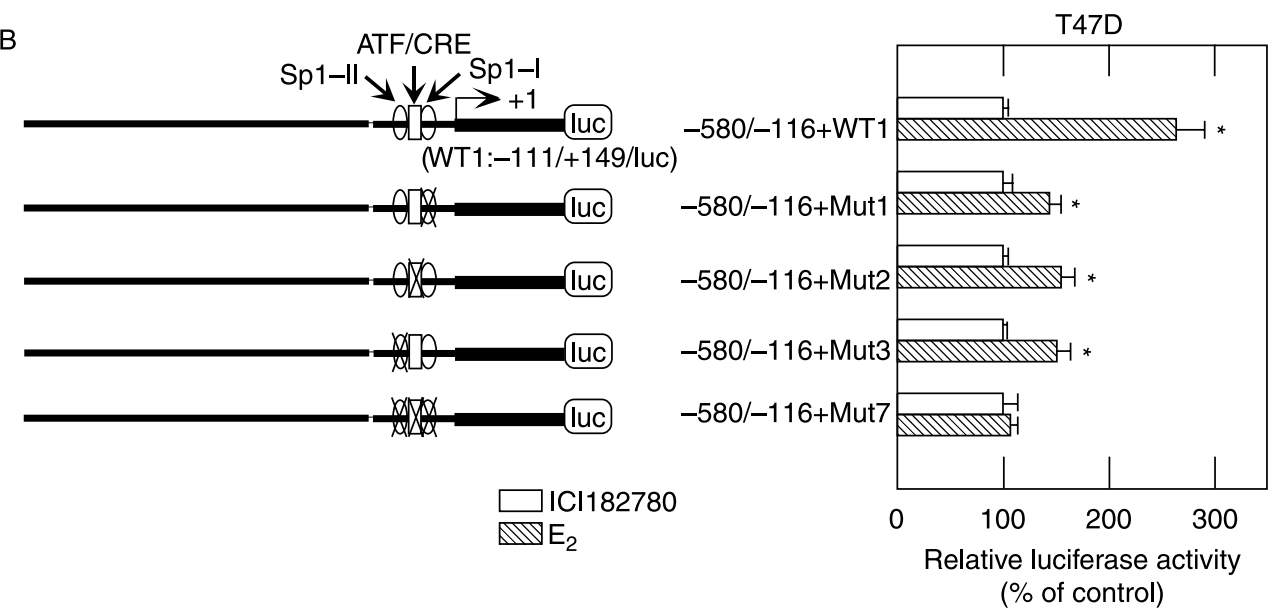


and 7 ) and $-388 /-326$ (lanes 5 and 10), but unaffected by $-361 /-329$ containing mutated half ERE (from GGTCA to GTACA; lanes 3 and 8). The bands $\mathrm{a}$ and $\mathrm{b}$ were abolished $\overline{\mathrm{by}}$ including anti-ER $\alpha$ and antiER $\beta$ respectively (lanes 13 and 15 ). Thus, both ER $\alpha$ and ER $\beta$ are able to bind to the ERE half-site that mediates the estrogen responsiveness in T47D cells.

To verify the role of ERs, we next examined using ChIP assay whether ER $\alpha$ and ER $\beta$ are recruited to the ERE half-site in T47D cells upon $\mathrm{E}_{2}$ treatment. After T47D cells were treated with $\mathrm{E}_{2}$ for various time, crosslinked sheared chromatin was immunoprecipitated with antibodies against $\mathrm{ER} \alpha$ and $\mathrm{ER} \beta$, and then the recovered DNA fraction was investigated by PCR to detect sst2 promoter region encompassing the ERE half-site (Fig. 8D). $\mathrm{E}_{2}$ increased the binding of ER $\alpha$ to the region between -457 and -276 , time dependently (lanes 1-4), whereas it did not to an intron region $(+968 /+1121)$ as a reference (lanes 5 and 6$)$. After a 1-h treatment with $E_{2}$, amount of the recruited ER $\alpha$ increased approximately ninefold over the untreated control value (Fig. 8D, right panel). On the other hand, no obvious binding of ER $\beta$ to this region was observed after 1- and 24-h treatment with $\mathrm{E}_{2}$ (Fig. 8D, lanes 7-9), although ER $\beta$ mRNA expression is reportedly up-regulated by $\mathrm{E}_{2}$ in T47D cells (Kietz et al. 2004). Taken together, these results obtained in T47D cells at least demonstrate that the distal $\mathrm{E}_{2}$ responsiveness is achieved via the recruitment of $\mathrm{E}_{2}$-activated $\mathrm{ER} \alpha$ to the region containing half ERE.

\section{Discussion}

In the present study, we disclosed for the first time detailed structural and functional features of the $5^{\prime}$ flanking region of the human sst 2 gene and identified cis-regulatory elements and trans-acting factors in the newly characterized promoter. We also established the molecular basis for the estrogen responsiveness that occurs through both ATF/CRE and Sp1 sites present in the minimal promoter, in combination with the distal region containing an ERE half-site and a GC-rich sequence, dependently on cell context (Fig. 9).
According to the present study in conjunction with others including that of MGC Program Team (Strausberg et al. 2002), the existence of an additional exon 1 and an intron in the $5^{\prime}$-upstream of the coding region was defined. The exon 1 was identified in the tissues such as brain and pancreas and cell lines of human origin tested. The size of exon 1 was determined to consist of $257 \mathrm{bp}$ in the present study compared with $268 \mathrm{bp}$ in the human retinoblastoma (Strausberg et al. 2002) and $276 \mathrm{bp}$ in the fetal brain (GenBank accession number, CR593522). The $5^{\prime}$-flanking region of the human sst2 gene contained Sp1 and ATF/CRE sites in the minimal promoter. The newly determined structure of the human sst2 gene and its transcriptional regulatory region, which show a high similarity to the rat gene (Kimura et al. 2001), make a sharp contrast with previous reports on the human gene, in which the transcriptional start sites were located between 83 and 93 bp upstream of the ATG codon (Pscherer et al. 1996, Xu et al. 1998, Petersenn et al. 1999). However, since a previous report showed that the corresponding region of the human SSTR2inr is used in mouse tissues including brain, lung, kidney, and spleen (Kraus et al. 1998), it cannot be ruled out that the sequence encompassing the intron 1 and exon 2 located in the proximity of the ATG codon may operate as well in a species-dependent manner.

The present study revealed that Sp1-I site is activated by $\mathrm{Sp} 1$ protein. However, it would be worth mentioning that while MUT1 lacking Sp1-I site resulted in a decrease in the promoter activity in HeLa cells, this decrease was not observed in $\mathrm{GH}_{3}$ and T47D cells. The observation in $\mathrm{GH}_{3}$ cells can be explained by low expression of Sp1 (Coleman et al. 1992), but this is not the case in T47D cells since the cell expresses Sp1 protein (Fujita et al. 2004). Simplest explanation for the latter case may be given from a finding that undetermined Sp1-related site(s) was suggested to exist between -25 and +149 in Drosophila SL2 cells (Fig. 5). This Sp1-related site might have compensated the Sp1-I in T47D cells. In contrast, Sp3 and Sp2 in addition to Sp1 were capable of acting on Sp1-II site. The Sp1-II, rather than the Sp1-I site, appears to contribute to the promoter activity in HeLa and T47D

Figure 7 Requirement of cis-elements for the estrogen responsiveness. (A) Sp1-I, Sp1-II, and ATF/CRE sites were required for the proximal estrogen responsiveness. Wild-type $\left(-111 /+149 /\right.$ luc, WT1) and mutated constructs (Mut1, 2, 3, 6) were transfected into GH $\mathrm{H}_{3}$ and T47D cells, as described in the legend of Fig. $6 \mathrm{~A}$ and $\mathrm{C}$. The relative luciferase activity of the $\mathrm{E}_{2}$-treated group is given as a percentage of the value of the ICl182780-treated groups. ${ }^{*} P<0.05$ compared with the value of the ICl182780-treated groups. (B) The minimal promoter region of human sst2 gene is essential for the distal estrogen responsiveness in T47D cells. The distal region from -580 to -116 was conjugated with WT1 and various mutants (Mut1, 2, 3, 7) to produce the $-580 /-116+$ WT1 and corresponding mutants ( $-580 /-116+$ Mut1 and so on). Nonspecific 14 nucleotides (CGAGCTCTTACGCG) were inserted between $-580 /-116$ and WT1 when the construct of $-580 /-116+$ WT1 and its mutants were prepared. ${ }^{*} P<0.05$ compared with the value of the ICl182780treated groups. (C) Requirement of GC-rich region for the distal estrogen responsiveness. After the $-580 /+149 /$ luc construct (WT2) and its deletion mutants as indicated were transfected into T47D cells, the cells were cultured as described in Fig. 6C. The relative luciferase activity of the $\mathrm{E}_{2}$-treated group is given as a percentage of the control without $\mathrm{E}_{2} .{ }^{\star} P<0.05$ compared with the value of WT2. 
as well as $\mathrm{GH}_{3}$ cells (Fig. 4). Together, transcription of the $s s t 2$ gene may be regulated through the Sp1-I and Sp1-II sites in concert under the balance between Sp family proteins expressed in a given cell type.

The human ATF/CRE consists of asymmetrical sequence (TGACGTAC), being in contrast with the rodent CRE of sst2 gene that comprises the consensus CRE palindrome (TGACGTCA; Kraus et al. 1998, Kimura et al. 2001). Interestingly, EMSA data revealed that the human sst2 ATF/CRE was capable of interacting with ATF2, c-Jun, and CREB, whereas ATF-2 and c-Jun proteins, but not CREB, bound to the rat sst2 CRE (Kimura et al. 2001). Whether this differential binding property is derived from species-specific CRE sequence remains to be further studied, since CREB binding to CRE sites of many genes reportedly takes place in a cell type-specific manner (Cha-Molstad et al. 2004).

We suggested that the up-regulation of sst2 transcription by $\mathrm{E}_{2}$ occurred through not only the proximal promoter region but also the further upstream region of the human sst 2 gene in T47D cells. As for the proximal promoter region, no canonical ERE was identified. In such an ERE-independent transactivation, ER is known to regulate transcription through protein-protein interaction by forming a complex with other transcription factors, such as c-Jun, Sp1, and Sp3 (Stoner et al. 2000, Castro-Rivera et al. 2001, Klinge 2001, O'Lone et al. 2004, Higgins et al. 2006).

A
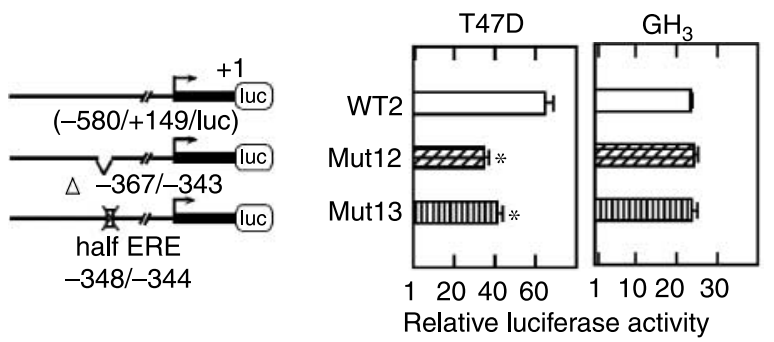

(fold activation)
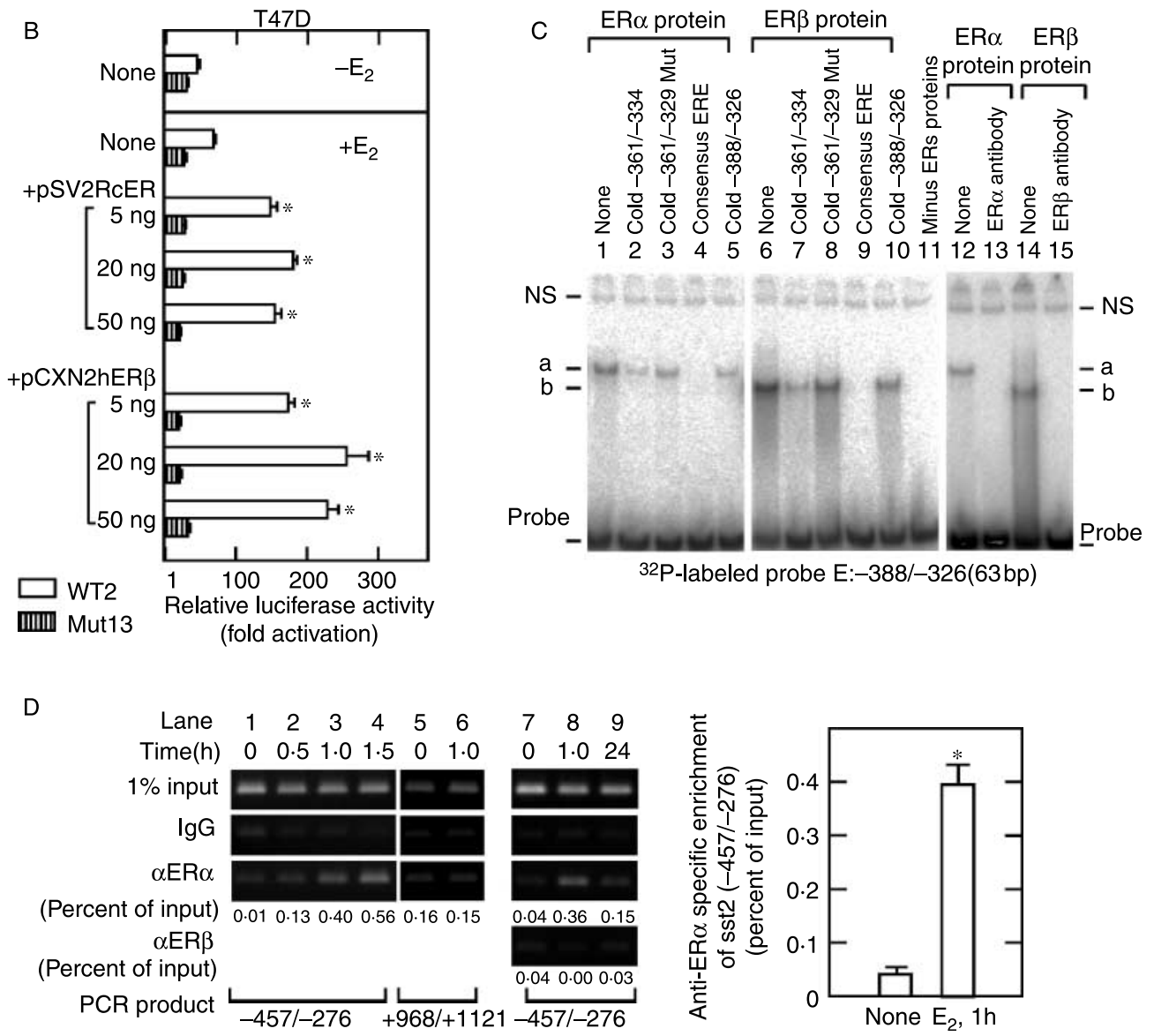


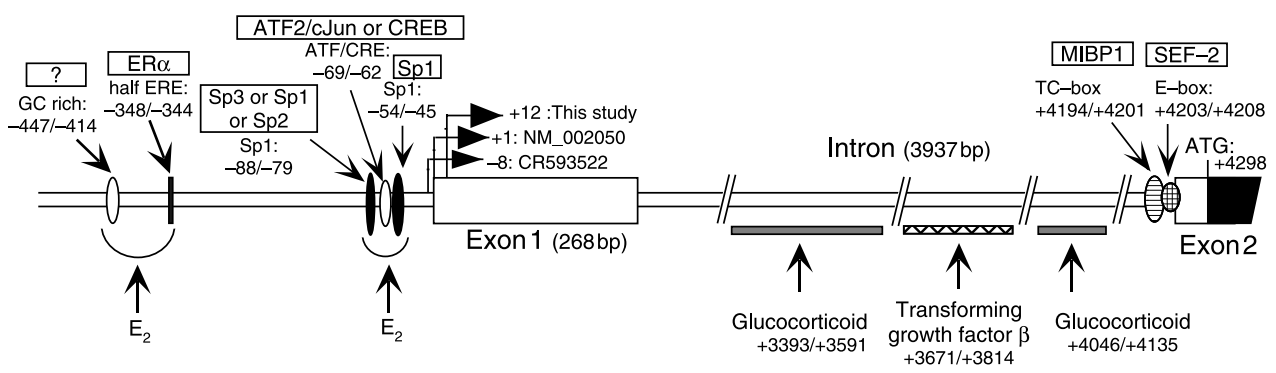

Figure 9 A schematic of the human sst2 promoter indicating the positions of transcriptional regulatory elements. The cis-acting elements and their trans-acting factors from the present study are demonstrated in the $5^{\prime}$-flanking region. In the intron region, two cis-elements, $\mathrm{E}$ and TC boxes, and the regions required for glucocorticoid and transforming growth factor $\beta$ responsiveness, which were previously documented (Pscherer et al. 1996, Dorflinger et al. 1999, Petersenn et al. 1999, Puente et al. 2001), are also illustrated. Each trans-acting factor is encircled with a square.

The $\mathrm{E}_{2}$-mediated activation that occurs at GC-rich sites is reported to take place through interacting with ER-Sp1 or ER-Sp3 complex (Castro-Rivera et al. 2001, Higgins et al. 2006), whereas $\mathrm{E}_{2}$-mediated inhibition is conveyed through interaction with ER-Sp3 complex (Stoner et al. 2000). In the light of the present observation that both CRE and Sp1 sites in the proximal promoter region are responsible for the $\mathrm{E}_{2}$ action, such a complex, ER-Sp1, ER-c-Jun/ATF-2, or ER-Sp3 may play a role in the transcriptional activation by $\mathrm{E}_{2}$.

Regarding the $\mathrm{E}_{2}$ responsiveness in the distal region, since more recent literatures demonstrated that FoxA1 interacts with FoxA1 motif and, in combination with ERE or ERE half-site, facilitates the interaction of ER with chromatin nucleosome in breast cancer cells (Laganiere et al. 2005, Carroll \& Brown 2006), we first wondered whether or not FoxA1-like protein binds to an AT-rich sequence $(-463 /-448)$. The present study, however, showed that the AT-rich region was irrelevant and rather implied that a GC-rich region $(-447 /-414)$ was critically important. The GC-rich region contained no typical consensus Sp1 sequence although three Sp1 sites with low matching scores were found by searching with a
TFSEARCH program (Heinemeyer et al. 1998). Nevertheless, the GC-rich region in conjunction with ERE halfsite is suggested as a possible target of ER. This assumption is based on a finding that $\mathrm{ER} \alpha$, when interacted with $\mathrm{Sp} 1$, is able to bind directly to a sequence with Sp1 (N) $)_{\mathrm{x}}$ ERE half or Sp1 (N) $)_{\mathrm{x}}$ ERE motifs (Safe 2001, O'Lone et al. 2004), in which the two consensus motifs are located at a distance with various lengths (Safe 2001). In the present case, the $-447 /-414$ region and the ERE half-site are located at a distance of about $65 \mathrm{bp}$. This distance is close to a length that encircles a single nucleosome, as discussed in metastasis-associated protein 3 promoter containing Sp1 (N) ${ }_{65}$ ERE half-site (Fujita et al. 2004). It could also be possible that ER may interact with still unidentified factor, recruit other nuclear protein(s) and, as a result, facilitate interaction with general transcription factors.

The present observation on the molecular link between $\mathrm{E}_{2}$, ERs, and sst2 may provide insights into some physiological and clinical issues. For example, besides the somatotrophs and mammotrophs in the pituitary and the breast cancer cells, several tissues such as prostate, stomach, and lung cancers express both ERs

Figure 8 Identification of half ERE in the distal estrogen-responsive region of the sst2 promoter. (A) Effect of deletion and mutation of putative ERE on the promoter activity. The $-580 /+149 /$ luc construct (WT2) and those with deletion from -367 to -343 (Mut 12 ) and with mutation in half ERE (Mut 13) were transfected into T47D or $\mathrm{GH}_{3}$ cells. After transfection, cells were grown in the normal growth medium containing $10^{-8} \mathrm{M} \mathrm{E}_{2}$ for $24 \mathrm{~h}$. ${ }^{*} P<0.05$ decrease compared with the value of WT2. (B) Overexpression of ER $\alpha$ and $E R \beta$ leads to an increase in promoter activity of WT2 but does not in the mutated half ERE construct (Mut13). The constructs of WT2 and Mut13 were cotransfected with varying dose of ER $\alpha$ expression vector (pSV2RcER) or ER $\beta$ expression vector (pCXN2hER $\beta$ ) into T47D cells. Cells were grown in the normal growth medium without (upper panel) or with $10^{-8} \mathrm{M} \mathrm{E}_{2}$ (lower panel) for $24 \mathrm{~h}$. Significant ( $\left.{ }^{\star} P<0 \cdot 001\right)$ activation by overexpression of $E R \alpha$ or $E R \beta$ compared with the $E_{2}$-plus control value. (C) EMSA of the distal promoter region containing the half $E R E$ site. Recombinant $E R \alpha$ or $E R \beta$ protein (each $750 \mathrm{fmol})$ and $E_{2}\left(5 \times 10^{-8} \mathrm{M}\right)$ was incubated with a ${ }^{32} \mathrm{P}$-labeled probe $E(-388 /-326)$ in the absence or presence of $100 \mathrm{ng}$ cold double-strand oligonucleotide $(-361 /-334,-361 /-329$ Mut and consensus ERE) or $30 \mathrm{ng}$ cold $-388 /-326$ as indicated in the panel (lanes 1-10). In a lane 11, no recombinant proteins were added in the incubation mixture. In lanes $12-15$, the recombinant ERs were preincubated without or with antibodies against $E R \alpha$ and $E R \beta$ and then incubated with a radiolabeled probe E. (D) Analysis on interaction of ERs with the region containing ERE half-site using ChIP assay. In the left panel, the chromatin preparations were isolated from T47D cells treated with $\mathrm{E}_{2}$ for indicated times, followed by immunoprecipitation using antibodies against $\mathrm{ER} \alpha(\alpha \mathrm{ER} \alpha)$, ER $\beta(\alpha \mathrm{ER} \beta)$, or IgG as a control. The region between -457 and -276 (lanes $1-4$, lanes $7-9$ ) or between +968 and +1121 (lanes 5 and 6) was amplified from the immunoprecipitated chromatin or $1 \%$ input, which was the preparation before immunoprecipitation. Semi-quantitated value of each band was shown as percent of the input. In the right panel, the binding of ER $\alpha$ to the region between -457 and -276 of the sst2 gene was demonstrated as percent of input in T47D cells treated with $E_{2}$ for $1 \mathrm{~h}$. Values represent the means \pm s.E.M. of five independent experiments. $\left({ }^{\star} P<0.001\right)$. 
and sst2 (Halmos et al. 2000, Campbell-Thompson et al. 2001, Dougherty et al. 2006), and in rodent central nervous system the arcuate nucleus expresses more sst2 in female than male (Shimizu et al. 2005, Bouyer et al. 2006). Since the expression of ERs is known to increase in progressed tumors (Deroo \& Korach 2006), it is expected that the increased ER proteins may lead to induce the sst 2 gene expression. In breast cancers, effectiveness of endocrine therapy is evaluated in terms of the sst2 expression level, relying on the fact that the sst2 expression is coupled with functional ER positivity (Van Den Bossche et al. 2006). On the other hand, recently, not only sst2-acting somatostatin analogues but also sst 2 gene therapy has been challenged in the treatment of a number of tumors. In the case of human pancreatic tumors that do not express sst2, gene therapy for sst2 has been considered as a potential approach to render tumors sensitive to sst2 agonists to suppress cell growth (Carrere et al. 2005). The present study demonstrated that both ATF-2 and c-Jun were required for full expression of the human sst2 gene. Some oncogenic proteins are known to be able to activate ATF-2 and c-Jun via mitogen- and stressactivated protein kinase signal transduction (van Dam \& Castellazzi 2001). Our present results may provide a clue to explain the phenomenon that the sst2 gene is highly expressed under tumorigenic environment. Together, elucidation of the molecular mechanism of regulating sst 2 gene expression should contribute to understanding molecular basis of tumor diagnosis and therapies.

\section{Acknowledgements}

The authors wish to thank Dr R Tjian (Howard Hughes Medical Institute, Univ. California) for generously sharing the pPac0 and pPacSp1, Dr J D Noti (Guthrie Research Institute, PA) for kindly providing pPacSp2 and pPacSp3, Drs M Muramatsu and S Inoue (Univ. Tokyo, Tokyo) for pSV2RcER and pCXN2hER $\beta$, and Dr H Nakata (TMIN, Tokyo) for his help and encouragement. The authors declare that there is no conflict of interest that would prejudice the impartiality of this scientific work.

\section{References}

Ben-Shlomo A, Wawrowsky KA, Proekt I, Wolkenfeld NM, Ren S-G, Taylor J, Culler MD \& Melmed S 2005 Somatostatin receptor type 5 modulates somatostatin receptor type 2 regulation of adrenocorticotropin secretion. Journal of Biological Chemistry $\mathbf{2 8 0}$ 24011-24021.

Bouyer K, Loudes C, Robinson ICAF, Epelbaum J \& Faivre-Bauman A 2006 Sexually dimorphic distribution of sst2A somatostatin receptors on growth hormone-releasing hormone neurons in mice. Endocrinology 147 2670-2674.
Campbell-Thompson M, Reyher KK \& Wilkinson LB 2001 Immunolocalization of estrogen receptor alpha and beta in gastric epithelium and enteric neurons. Journal of Endocrinology 171 65-73.

Carrere N, Vernejoul F, Souque A, Asnacios A, Vaysse N, Pradayrol L, Susini C, Buscail L \& Cordelier P 2005 Characterization of the bystander effect of somatostatin receptor sst2 after in vivo gene transfer into human pancreatic cancer cells. Human Gene Therapy 16 1175-1193.

Carroll JS \& Brown M 2006 Estrogen receptor target gene: an evolving concept. Molecular Endocrinology 20 1707-1714.

Castro-Rivera E, Samudio I \& Safe S 2001 Estrogen regulation of cyclin D1 gene expression in ZR-75 breast cancer cells involves multiple enhancer elements. Journal of Biological Chemistry 276 30853-30861.

Cha-Molstad H, Keller DM, Yochum GS, Impey S \& Goodman RH 2004 Cell-type-specific binding of the transcription factor CREB to the cAMP-response element. PNAS 101 13572-13577.

Coleman TA, Hou YT \& Kopchick JJ 1992 The SV40 early transcriptional regulatory element is unable to direct gene expression in pituitary GH3 cells. Gene Expression 2 175-189.

Courey AJ \& Tjian R 1988 Analysis of Sp1 in vivo reveals multiple transcriptional domains, including a novel glutamine-rich activation motif. Cell $\mathbf{5 5} 887-896$.

Dalm VA, van Hagen PM, van Koetsveld PM, Langerak AW, van der Lely AJ, Lamberts SW \& Hofland LJ 2003 Cortistatin rather than somatostatin as a potential endogenous ligand for somatostatin receptors in the human immune system. Journal of Clinical Endocrinology and Metabolism 88 270-276.

Van Dam H \& Castellazzi M 2001 Distinct roles of Jun:Fos and Jun:ATF dimmers in oncogenesis. Oncogene 20 2453-2464.

Day RN \& Maurer RA 1989 The distal enhancer region of the rat prolactin gene contains elements conferring response to multiple hormones. Molecular Endocrinology 3 3-9.

Van Den Bossche B, D'haeninck E, De Vos F, Dierckx RA, Van Belle S, Bracke M \& Van de Wiele C 2004 Oestrogen-mediated regulation of somatostatin receptor expression in human breast cancer cell lines assessed with ${ }^{99 \mathrm{~m}}$ Tc-depreotide. European Journal of Nuclear Medicine and Molecular Imaging 31 1022-1030.

Van Den Bossche B, Van Belle S, De Winter F, Signore A \& Van de Wiele C 2006 Early prediction of endocrine therapy effect in advanced breast cancer patients using ${ }^{99 \mathrm{~m}} \mathrm{Tc}$-depreotide scintigraphy. Journal of Nuclear Medicine 47 6-13.

Deroo BJ \& Korach KS 2006 Estrogen receptors and human disease. Journal of Clinical Investigation 116 561-570.

Djordjijevic D, Zhang J, Priam M, Viollet C, Gourdji D, Kordon C \& Epelbaum J 1998 Effect of $17 \beta$-estradiol on somatostatin receptor expression and inhibitory effects on growth hormone and prolactin release in rat pituitary cell cultures. Endocrinology 139 2272-2277.

Dorflinger U, Pscherer A, Moser M, Rummele P, Schule R \& Buettner R 1999 Activation of somatostatin receptor II expression by transcription factors MIBP1 and SEF-2 in the murine brain. Molecular and Cellular Biology 19 3736-3747.

Dougherty SM, Mazhawidza W, Bohn AR, Robinson KA, Mattingly KA, Blankenship KA, Huff MO, McGregor WG \& Klinge CM 2006 Gender difference in the activity but not expression of estrogen receptors $\alpha$ and $\beta$ in human lung adenocarcinoma cells. EndocrineRelated Cancer 13 113-134

Dutar P, Vaillend C, Viollet C, Billard JM, Potier B, Carlo AS, Ungerer A \& Epelbaum J 2002 Spatial learning and synaptic hippocampal plasticity in type 2 somatostatin receptor knock-out mice. Neuroscience 112 455-466.

Fujita N, Kajita M, Taysavang P \& Wade PA 2004 Hormonal regulation of metastasis-associated protein 3 transcription in breast cancer cells. Molecular Endocrinology 18 2937-2949.

Hagen G, Muller S, Beato M \& Suske G 1992 Cloning by recognition site screening of two novel GT box binding proteins: a family of Sp1 related genes. Nucleic Acids Research 20 5519-5525.

Halmos G, Schally AV, Sun B, Davis R, Bostwick DG \& Plonowski A 2000 High expression of somatostatin receptors and messenger 
ribonucleic acid for its receptor subtypes in organ-confined and locally advanced human prostate cancers. Journal of Clinical Endocrinology and Metabolism 85 2564-2571.

Heinemeyer T, Wingender E, Reuter I, Hermjakob H, Kei AE, Kei OV, Ignatieva EV, Ananko EA, Podkolodnaya OA, Kolpakov FA et al. 1998 Database on transcriptional regulation: TRANSFAC, TRRD, and CMPEL. Nucleic Acids Research 26 362-367.

Higgins KJ, Liu S, Abdelrahim M, Yoon K, Vanderlaag K, Porter W, Metz RP \& Safe S 2006 Vascular endothelial growth factor receptor2 expression is induced by $17 \beta$-estradiol in ZR-75 breast cancer cells by estrogen receptor $\alpha /$ Sp proteins. Endocrinology 147 3285-3295.

Hofland LJ \& Lamberts SW 2003 The pathophysiological consequences of somatostatin receptor internalization and resistance. Endocrine Reviews 24 28-47.

Jordan VC \& Morrow M 1999 Tamoxifen, raloxifene and the prevention of breast cancer. Endocrine Reviews 20 253-278.

Kietz S, Thomsen JS, Matthews J, Pettersson K, Strom A \& Gustafsson J-A 2004 The Ah receptor inhibits estrogen-induced estrogen receptor $\beta$ in breast cancer cells. Biochemical and Biophysical Research Communications 320 76-82.

Kimura N \& Takamatsu N 2002 Analysis of a novel promoter region of the human somatostatin receptor sst2 gene (Abstract, Japanese): Proceeding of the 29th Annual Meeting of The Japan Neuroendocrine Society, 2002, Kochi, Japan. Folia Endocrinologica Japonica 78313.

Kimura N, Hayafuji C, Konagaya H \& Takahashi K 1986 17-3-Estradiolinduced somatostatin (SRIF) inhibition of prolactin release and regulates SRIF receptors in rat anterior pituitary cells. Endocrinology 119 1028-1036.

Kimura N, Hayafuji C \& Kimura N 1989 Characterization of 17- $\beta$-estradioldependent and -independent somatostatin receptor subtypes in rat anterior pituitary. Journal of Biological Chemistry 264 7033-7040.

Kimura N, Tomizawa S, Arai KN \& Kimura N 1998 Chronic treatment with estrogen up-regulates expression of sst2 messenger ribonucleic acid (mRNA), but down-regulates expression of sst5 mRNA in rat pituitaries. Endocrinology 139 1573-1580.

Kimura N, Tomizawa S, Arai KN, Osamura RY \& Kimura N 2001 Characterization of $5^{\prime}$-flanking region of rat somatostatin receptor sst2 gene: transcriptional regulatory elements and activation by Pitxl and estrogen. Endocrinology 142 1427-1441.

Klinge CM 2001 Estrogen receptor interaction with estrogen response elements. Nucleic Acids Research 29 2905-2919.

Krantic S, Goddard I, Saveanu A, Giannetti N, Fombonne J, Cardoso A, Jaquet P \& Enjalbert A 2004 Novel modalities of somatostatin actions. European Journal of Endocrinology 151 643-655.

Kraus J, Woltje M, Schonwetter N \& Hollt V 1998 Alternative promoter usage and tissue specific expression of the mouse somatostatin receptor 2 gene. FEBS Letters 428 165-170.

Laganiere J, Deblois G, Lefebvre C, Bataille AR, Robert F \& Giguere V 2005 Location analysis of estrogen receptor $\alpha$ target promoters reveals that FOXAl defines a domain of the estrogen response. PNAS 102 11651-11656.

Martinez V, Curi AP, Torkian B, Schaeffer JM, Wilkinson HA, Walsh JH \& Tache Y 1998 High basal gastric acid secretion in somatostatin receptor subtype 2 knockout mice. Gastroenterology 114 1125-11327.

Murdie P $2006{ }^{99 \mathrm{~m}} \mathrm{Tc}-\mathrm{DS}$ predicts response to endocrine therapy in advanced breast cancer patients. Nature Clinical Practice. Oncology 3174.

Noti JD 1997 Sp3 mediates transcriptional activation of the leukocyte integrin genes CD11c and CD11b and cooperates with c-jun to activate CD11c. Journal of Biological Chemistry 272 24038-24045.

Ogawa S, Inoue S, Watanabe T, Hiroi H, Orimo A, Hosoi T, Ouchi Y \& Muramatsu M 1998 The complete primary structure of human estrogen receptor $\beta$ (hER $\beta$ ) and its heterodimerization with ER $\alpha$ in vivo and in vitro. Biochemical and Biophysical Research Communications 243 122-126.

Ohashi M, Aizawa S, Ooka H, Ohsawa T, Kaji K, Kondo H, Kobayashi T, Noumura T, Matsuo M, Mitsui Y et al. 1980 A new human diploid cell strain, TIG-1, for the research on cellular aging. Experimental Gerontology 15 121-133.
Olias G, Viollet C, Kusserow H, Epelbaum J \& Meyerhof W 2004 Regulation and function of somatostatin receptors. Journal of Neurochemistry 89 1057-1091.

O'Lone R, Frith MC, Karlsson EK \& Hansen U 2004 Genomic targets of nuclear estrogen receptors. Molecular Endocrinology 18 1859-1875.

Orlando C, Casini Raggi C, Bianchi S, Distante V, Simi L, Vezzosi V, Gelmini S, Pinzani P, Cameron Smith M, Buonamano A et al. 2004 Measurement of somatostatin receptor subtype 2 mRNA in breast cancer and corresponding normal tissue. Endocrine-Related Cancer 11 323-332.

Patel YC 1999 Somatostatin and its receptor family. Frontiers in Neuroendocrinology 20 157-198.

Petersenn S, Rasch AC, Presch S, Beil FU \& Schulte HM 1999 Genomic structure and transcriptional regulation of the human somatostatin receptor type 2. Molecular and Cellular Endocrinology 157 75-85.

Pscherer A, Dorflinger U, Kirfel J, Gawlas K, Ruschoff J, Buettner R \& Schule R 1996 The helix-loop-helix transcription factor SEF-2 regulates the activity of a novel initiator element in the promoter of the human somatostatin receptor II gene. EMBO Journal 15 6680-6690.

Puente E, Saint-Laurent N, Torrisani J, Furet C, Schally AV, Vaysse N, Buscail L \& Susini C 2001 Transcriptional activation of mouse sst2 somatostatin receptor promoter by transforming growth factor- $\beta$. Involvement of Smad4. Journal of Biological Chemistry 276 13461-13468.

Ren S-G, Taylor J, Dong J, Yu R, Culler MD \& Melmed S 2003 Functional association of somatostatin receptor subtypes 2 and 5 in inhibiting human growth hormone secretion. Journal of Clinical Endocrinology and Metabolism 88 4239-4245.

Reubi JC 2003 Peptide receptors as molecular targets for cancer diagnosis and therapy. Endocrine Reviews 24 389-427.

Safe S 2001 Transcriptional activation of genes by $17 \beta$-estradiol through estrogen receptor-Spl interactions. Vitamins and Hormones 62 231-252.

Shimizu T, Kamegai J, Tamura H, Ishii S, Sugihara H \& Oikawa S 2005 The estrogen receptor (ER) $\alpha$, but not ER $\beta$, gene is expressed in hypothalamic growth hormone-releasing hormone neurons of the adult female rat. Neuroscience Research 52 121-125.

Stoner M, Wang F, Wormke M, Nguyen T, Samudio I, Vyhlidal C, Marme D, Finkenzeller G \& Safe S 2000 Inhibition of vascular endothelial growth factor expression in HEC1A endometrial cancer cells through interactions of estrogen receptor $\alpha$ and Sp3 proteins. Journal of Biological Chemistry 275 22769-22779.

Strausberg RL, Feingold EA, Grouse LH, Derge JG, Klausner RD, Collins FS, Wagner L, Shenmen CM, Schuler GD, Altschul SF et al. 2002 Generation and initial analysis of more than 15000 full-length human and mouse cDNA sequences. PNAS 99 16899-16903.

Suske G 1999 The Sp-family of transcription factors. Gene 238 291-300.

Xu Y, Song J, Berelowitz M \& Bruno JF 1996 Estrogen regulates somatostatin receptor subtype 2 messenger ribonucleic acid expression in human breast cancer cells. Endocrinology $1375634-5640$.

Xu Y, Berelowitz M \& Bruno JF 1998 Characterization of the promoter region of the human somatostatin receptor subtype 2 gene and localization of sequences required for estrogen-responsiveness. Molecular and Cellular Endocrinology 139 71-77.

Yamada Y, Post SR, Wang K, Tager HS, Bell GI \& Seino S 1992 Cloning and functional characterization of a family of human and mouse somatostatin receptors expressed in brain, gastrointestinal tract, and kidney. PNAS 89 251-255.

Zheng H, Bailey A, Jiang MH, Honda K, Chen HY, Trumbauer ME, Van der Ploeg LH, Schaeffer JM, Leng G \& Smith RG 1997 Somatostatin receptor subtype 2 knockout mice are refractory to growth hormone-negative feedback on arcuate neurons. Molecular Endocrinology 11 1709-1717.

Received in final form 24 October 2007

Accepted 26 November 2007

Made available online as an Accepted Preprint

26 November 2007 